\title{
The impact of low sulphur fuel requirements in shipping on the competitiveness of roro shipping in Northern Europe
}

\author{
Theo Notteboom
}

Accepted: 16 August 2010 / Published online: 3 November 2010

(C) World Maritime University 2011

\begin{abstract}
Annex VI of the MARPOL Convention aims for a reduction in sulphur oxide emissions from ships. The limits applicable at sea in Emission Control Areas (ECAs) were reduced from $1.5 \%$ to $1 \%$ in 2010 and are planned to be further reduced to $0.1 \%$, effective from 1 January 2015 . This paper analyses the impact of the International Maritime Organization's Tier II/III standards introduced by Annex VI amendments adopted in October 2008 on costs and prices of roro (roll on/roll off) traffic in the ECAs in North Europe and on the competitiveness of roro shipping in the ECAs compared to trucking. We demonstrate that the new Annex VI agreement may be quite costly for the participants in the shipping industry and will result in higher freight rates. Based on a detailed price analysis on modal competition between the roro/truck option and the 'truck only' option on thirty origin-destination routes linked to the ECAs, we conclude that the use of low sulphur fuel is expected to increase the transport prices particularly on the origin-destination relations with a medium or long short sea section. The paper also presents the results of a survey among leading short sea operators in the ECAs in view of providing more insight on expected modal shifts and price elasticity in the short sea market.
\end{abstract}

Keywords Roro shipping $\cdot$ Fuel costs $\cdot$ Modal competition $\cdot$ Baltic $\cdot$ Sulphur $\cdot$ IMO

\section{Introduction}

Transportation causes environmental effects in the form of greenhouse gas (GHG) emissions such as $\mathrm{CO}_{2}$ with an impact on climate change and non-GHG emissions such as $\mathrm{NO}_{\mathrm{x}}, \mathrm{SO}_{2}$, volatile organic compounds and particulate organic matter with an impact on local air quality and consequently on nature and health. An abundant literature discusses the nature and extent of the environmental damage caused by

T. Notteboom $(\bowtie)$

Institute of Transport and Maritime Management Antwerp (ITMMA), University of Antwerp,

Keizerstraat 64, 2000 Antwerp, Belgium

e-mail: theo.notteboom@ua.ac.be 
transport modes (see, e.g. Banister and Button 1993; Chapman 2007). A number of these studies focus on ship emissions and related policy measures (Endresen et al. 2003; Corbett and Koehler 2003; Derwent et al. 2005; Eyring et al. 2007; Eyring et al. 2009; Wang et al. 2009; Psaraftis and Kontovasa 2010). Harmful emissions represent a social cost to society particularly when these environmental effects are not properly internalised in the transport price (i.e. external costs; see, e.g. Van Wee et al. 2005; Friedrich and Bickel 2001).

The impact of new environmental regulations on transport markets is a much discussed issue in recent literature, particularly in the context of the competition between transport modes (Campisi and Gastaldi 1996; Potter and Enoch 1997; Cofala 2007). This paper discusses the impact of specific environmental legislation of the International Maritime Organization (IMO) regarding vessel emissions on modal competition between maritime transport and road haulage. The ship pollution rules of IMO are contained in the International Convention on the Prevention of Pollution from Ships, known as MARPOL 73/78. On 27 September 1997, the MARPOL Convention has been amended by the 1997 Protocol, which includes Annex VI titled 'Regulations for the Prevention of Air Pollution from Ships'. MARPOL Annex VI sets limits on $\mathrm{NO}_{\mathrm{x}}$ and sulphur oxide $\left(\mathrm{SO}_{\mathrm{x}}\right)$ emissions from ship exhausts and prohibits deliberate emissions of ozone depleting substances. The IMO emission standards are commonly referred to as Tier I, II and III standards. The Tier I standards were defined in the 1997 version of Annex VI, while the Tier II/III standards were introduced by Annex VI amendments adopted in October 2008. Annex VI aims for a reduction in $\mathrm{SO}_{\mathrm{x}}$ emissions from ships, with the global sulphur cap reduced initially to $3.5 \%$ (from the current $4.5 \%$ ), effective from 1 January 2012; then progressively to $0.5 \%$, effective from 1 January 2020 , subject to a feasibility review to be completed no later than 2018. The limits applicable in Emission Control Areas (ECAs) were reduced from $1.5 \%$ to $1 \%$ in 2010 and are planned to be further reduced to $0.1 \%$, effective from 1 January 2015 . There are also provisions for sulphur caps in marine fuels for vessels in ports.

There are currently three ECAs in the world, all situated in North Europe, i.e. the North Sea, the Baltic Sea and the English Channel. The limitation of sulphur content in bunkers for ships sailing in ECAs has some history. The first ECA is the Baltic Sea entered into force on the 19 May 2006 with a maximum sulphur content of $1.5 \%$. The North Sea Area and the English Channel ECA entered into force on 22 November 2007. The ECA area represents about $0.3 \%$ of the world's water surface. The ECAs do not include any other European waters such as the Irish Sea, Mediterranean Sea and Black Sea.

The policy focus on a reduction of sulphur in ship fuels stems from its contribution to environmental pollution. As the sulphur in fuels burn, it will form $\mathrm{SO}_{\mathrm{x}}$, which is one of the pollutants to the environment especially in the formation of acid rain. Continued exposure over a long time changes the natural variety of plants and animals in an ecosystem. The sulphur content in fuel oil has a large impact on the particle level in the exhaust gas. Ships have two options to reduce sulphur emissions in the ECAs: switch to low sulphur fuel oil or use scrubbers:

- Switch to low sulphur fuel oil (LSFO). The time it takes to flush the fuel oil system is a function of the sulphur content in high and low sulphur fuel oil, the 
mount of high sulphur fuel oil (HSFO) between first point of blending and engine inlet and the fuel oil consumption rate. The fuel oil system for switching to low sulphur fuel oil ideally allows LSFO to be completely segregated from HSFO from the storage to the service tank. Blending will only take place in the piping between the service tanks and the inlet to the engine.

- The use of scrubbers. Instead of using LSFO in ECAs, ships can fit an exhaust gas cleaning system or use any other technological method to limit $\mathrm{SO}_{\mathrm{x}}$ emissions. Since scrubber technology is evolving rapidly, it is not entirely clear whether the costs of the use of scrubbers are competitive to the use of LSFO. The development of stack scrubbers for ships is still at an early stage, and local authorities may prohibit discharging waste streams from scrubbers in ports and estuaries. The disposal problem seriously undermines future large-scale deployment of scrubbers. There is also a space issue when retrofitting scrubbers to existing vessels linked to the engine casing and acid-proof coated tanks. Krystallon (2008) argues there is a net $\mathrm{CO}_{2}$ benefit from the use of high sulphur fuel oil and scrubbers. Although the scrubber incurs $\mathrm{CO}_{2}$ emissions for neutralisation and for scrubber additional fuel consumption, this would be significantly less than the $\mathrm{CO}_{2}$ emitted by the additional refinery processing of the distillate. On-going development of scrubbing technology will inevitably lead to lower energy demand and may in the future be capable of scrubbing out other gases such as nitrogen oxides.

This paper analyses the impact of the IMO's Tier II/III standards introduced by Annex VI amendments adopted in October 2008 to roro (roll on/roll off) shipping in Northern Europe. The amendments to Annex VI have raised great concern among shipping lines operational in the ECAs as they fear that the reduction of the sulphur content in marine fuels to $0.1 \%$ by 2015 (compared to $1.5 \%$ prior to 2010 and $1 \%$ from 2010) might lead to (a) a serious disruption of the commercial dynamics of shipping in the ECAs, (b) a considerable increase in vessel operating costs, (c) a lower competitiveness compared to other transport modes and (d) a modal 'back shift' from sea to road, which would contradict the objective of the European Commission of promoting the use of sea/short sea transport. This paper particularly focuses on two research questions:

What is the expected impact of the new requirements of IMO on costs and prices of roro traffic in the ECAs?

What is the expected impact of the new requirements of IMO on the competitiveness of roro shipping in the ECAs compared to other transport modes (trucking in particular)?

In view of answering the research questions, the paper is organized as follows. The first section of the paper focuses on the first research question. Current and past price levels for marine fuel oils and the share of the fuel costs in total vessel operating costs are analysed. Next, the paper provides an analysis of the expected cost and price increases linked to the use of the new low sulphur percentages. The second section of the paper focuses on the second research question. A detailed price analysis is developed to assess modal competition between the roro/truck option and the 'truck only' option on 30 origin-destination routes linked to the ECAs. The 
'truck only' option means that a truck is used all the way from origin to destination without including a short sea section. In order to move from observed price differences to modal shift figures, we use a stated-preference technique based on a survey among leading short sea operators in the ECAs.

This paper follows a pure economic perspective on the impact of the low sulphur fuel requirements of IMO on short sea shipping in the ECAs. The paper is partly based on a study on the impact of low sulphur fuel requirements commissioned by the European Community Shipowners' Associations, see Notteboom et al. (2010). The ecological impact in terms of overall emissions is not part of the analysis provided in this paper. We refer to Vanherle and Delhaye (2010) for an extensive comparison of emissions and external costs for road versus short sea shipping for the same case studies as developed in this paper.

\section{The evolution of bunker fuel prices}

Bunker prices constantly fluctuate due to market forces and the cost of crude oil. Compared to diesel for trucks, the price evolution for marine fuel oils is more in line with the oil price. About $80 \%$ of the total bunker fuel relates to heavy fuel oil. Heavy fuel oil (HFO) mainly consists of residual refinery streams from the distillation or cracking units in the refineries. Intermediate fuel oil (IFO) 380 is a mix of $98 \%$ of residual oil and $2 \%$ of distillate oil, while IFO 180 is a mix of $88 \%$ of residual oil and $12 \%$ of distillate oil. Other bunker fuels than the HFO are the marine diesel oil (MDO), which mainly consists of distillate oil, and the marine gas oil (MGO), which is a pure distillate oil and has the lowest sulphur content.

Figure 1 reveals that the price difference between IFO 380 and MGO $(0.1 \%$ sulphur) fluctuates strongly in time (30\% to $250 \%$ price difference). The moving annual average ranges from $52 \%$ to $155 \%$ and the long-term average amounts to 93\% (period 1990-2008). The price difference between LS 380 and MDO fluctuates between $40 \%$ and $190 \%$, with a long-term average of $87 \%$. In other words, the specified MDO is on average $87 \%$ more expensive than LS 380. Overall, the cost of marine distillate fuels is about twice what residual fuels costs due to increasing demand and the cost of the desulphurisation process. These are long-term averages. The compulsory use of low sulphur fuel of maximum $0.1 \%$ in ECAs by 2015 would thus lead to a significant increase in the bunker costs for shipping lines. There are four points to be made in this respect.

First of all, it is very difficult to forecast the evolution of the fuel prices and with it the future price gaps between IFO, MDO and MGO. As mentioned earlier, the oil price is a determining factor together with the demand/supply balance for each of the marine fuel grades. Whether the global refining industry is willing and able to produce the required volume of distillates implied by the regulation is an important issue. Several sources underline that the oil industry will be able to process sufficient low sulphur fuel until 2015 in order to meet shipping's requirements within the ECAs (see, e.g. Swedish Maritime Administration 2009). Oil company BP argues that there are adequate avails of lower sulphur residual material but at increasing prices due to processes of re-blending, additional blending, sweeter crude oil slates and residual desulphurisation. EC-DG Environment (2002) concludes that to supply 


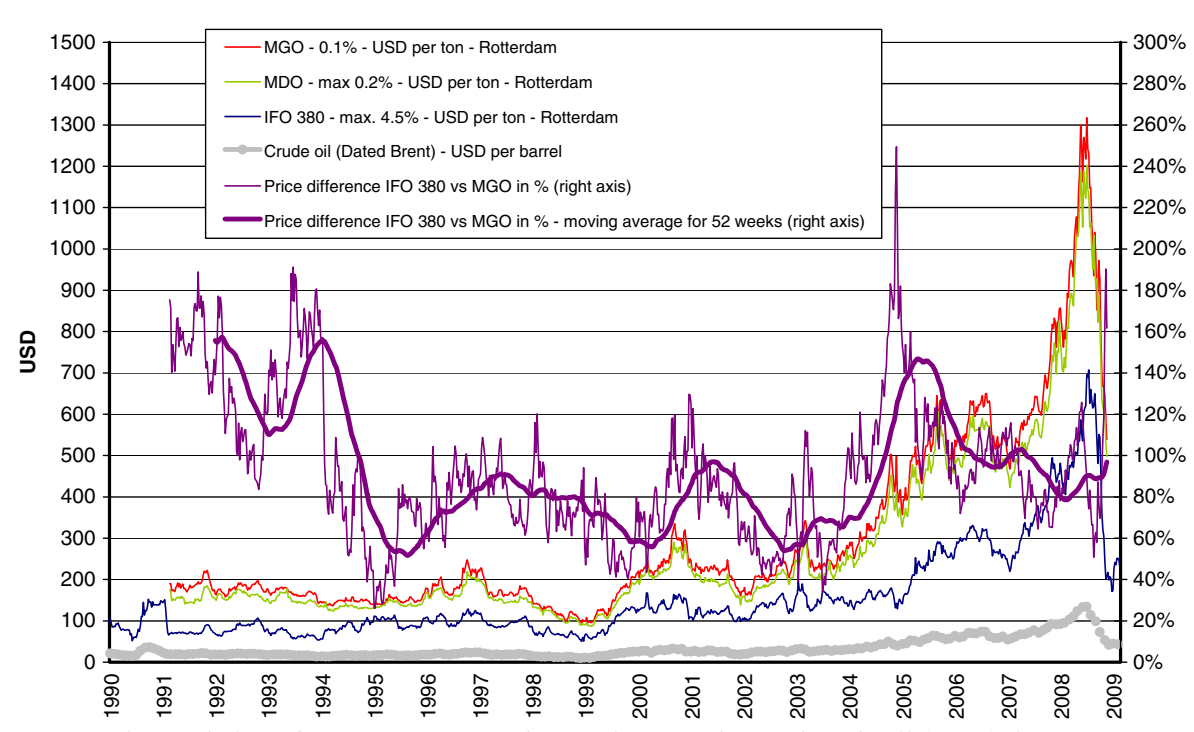

Fig. 1 Price evolution of IFO 380, MDO and MGO in Rotterdam and crude oil (Brent), in USD per ton (source: own compilation based on data Clarkson)

fuels with lower sulphur content specifications than 1.5\%, the European refining industry would need to invest in additional middle distillate desulphurisation capacity.

Second, the impact of oil price increases on the bunker cost for shipping is much more direct than in the case of trucking as a large part of the diesel price for trucks consists of taxes.

Third, the trucking industry shows much more flexibility in adapting to changing rules regarding emissions. One of the reasons is that trucks are amortized over a period of 3 to 4 years, while in shipping vessels have a much longer lifecycle, typically 20 to 25 years. In other words, it only takes a few years for the trucking industry to renew a fleet, while in shipping much more time is needed. The result is that energy efficiency gains due to new technologies develop rather fast in the trucking industry, but need more implementation time in the shipping industry.

Fourth, shipowners are likely to benefit in technical terms from using low sulphur fuels. For instance, apart from causing less pollution to the environment, distillate fuels also have higher thermal value which reduces engine wear (requiring less frequent maintenance) and lowers fuel consumption. Distillate fuel has a lower density than residual fuel oil, and it also has a higher energy content (HFO circa $40 \mathrm{MJ} / \mathrm{kg}$, Diesel Oil circa $42 \mathrm{MJ} / \mathrm{kg}$ ). Also, distillate fuel is of higher quality that results in less sludge on board and thereby benefits the operators who are finding it increasingly difficult to dispose sludge on shore. Improvement in the vessel's engine maintenance is expected to help mitigate the impacts of increased fuel costs.

Overall, the effect of the new Annex VI agreement may be quite costly for the participants in the shipping industry. Based on historical price differences, the use of MGO $(0.1 \%)$ could well imply a cost increase per ton of bunker fuel of on average 
$80 \%$ to $100 \%$ (long term) compared to IFO 380 and $70 \%$ to $90 \%$ compared to LS 380 grades $(1.5 \%)$. This conclusion is in line with Skogs Industrierna (2009). The price curve when moving from $1.5 \%$ sulphur content (LS 380) to $0.1 \%$ does not show a linear shape. A shift from $1.5 \%$ to $0.5 \%$ sulphur content represents an estimated cost increase of $20 \%$ to $30 \%$. The price effect when moving from $0.5 \%$ to $0.1 \%$ sulphur content is much more substantial with a $50 \%$ to $60 \%$ bunker cost increase. The combined effect of these percentages corresponds to a total cost increase of $70 \%$ to $90 \%$ compared to LS 380 grades $(1.5 \%)$.

The next section will assess the ramifications of these price increases on the total ship costs of vessels operating in the waters of the ECAs and thus also on the pricing strategies of shipping lines.

\section{Fuel costs for short sea vessels in the ECAs}

Notteboom and Vernimmen (2009) have demonstrated that bunkers represent a considerable cost factor to shipping lines. Figure 2 shows the relationship between the sailing distance and the fuel consumed in ton per $\mathrm{km}$ for a sample of traditional short sea and ropax vessels with an average commercial speed of 18.5 knots. The data were obtained from two major operators in the short sea business with services spread over the ECAs. For confidentiality reasons the origin-destination relations of the services could not be revealed. The scatter plot reveals that the fuel consumption typically ranges between 0.06 and 0.09 ton per $\mathrm{km}$. The range in fuel consumption of short sea vessels is attributable to operational and technical factors such as the unit capacity of the vessel (in dwt and in lane meters), the engine type, vessel age and weather conditions on the liner service. The sailing distance does not seem to

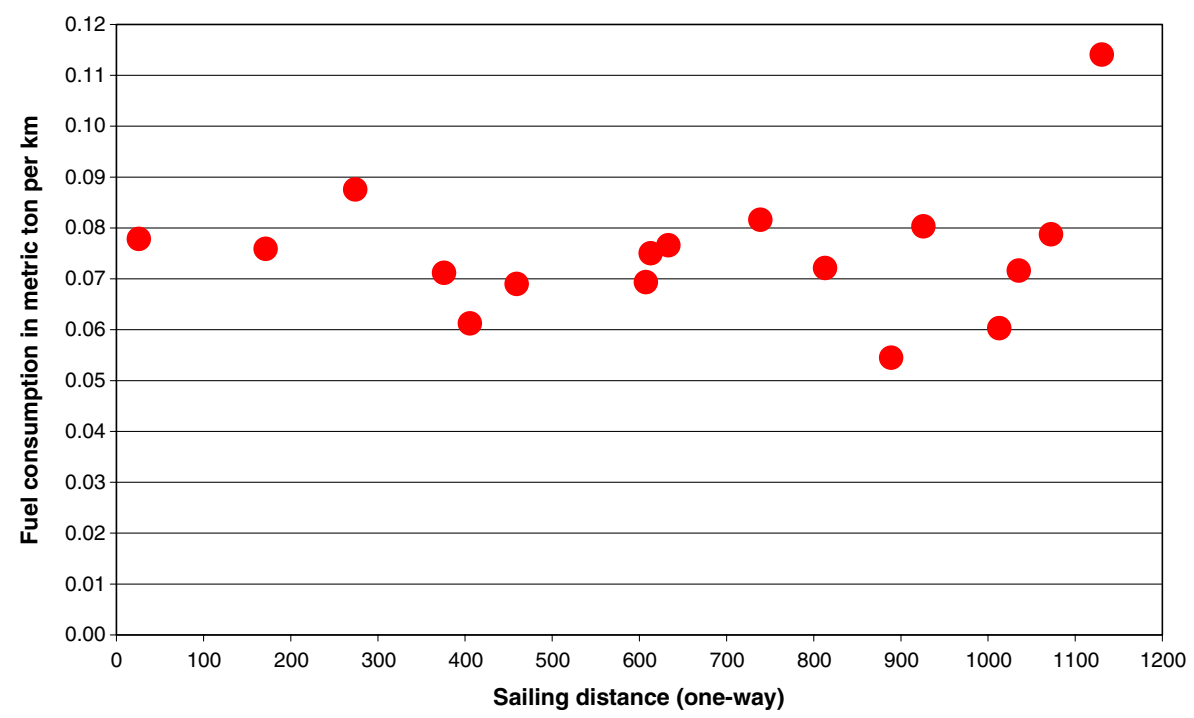

Fig. 2 Fuel consumption in metric ton per kilometer for a sample of short sea vessels (speed of 18.5 knots; source: based on data provided by ship operators) 
have a large impact on the fuel consumption per kilometer. The same sample reveals that the fuel consumption for faster short sea vessels (commercial speeds between 25 and 30 knots) typically amounts to 0.16 to 0.20 ton per $\mathrm{km}$ or more than double the consumption levels of the more standard vessels.

Using these fuel consumption data, we estimate the total fuel cost as a function of sailing distance for three scenarios of fuel price development of MGO $(0.1 \%$ sulphur content): USD 500 per ton, USD 750 per ton and USD 1,000 per ton. In the previous section, we pointed a cost increase per ton of bunker fuel of between $70 \%$ and $90 \%$ when moving from HFO (1.5\%) to MGO $(0.1 \%)$. These percentages are long-term averages. The price difference between MGO and HFO in the three scenarios is therefore set at $80 \%$, meaning that $\mathrm{MGO}$ is expected to be $80 \%$ more expensive than HFO (1.5\%). The base prices per ton in USD and euro are presented in Table 1. Figure 1 revealed that USD 500 per ton was the typical price level in the period 2005-2007 and the first half of 2009, while USD 1,000 per ton of MGO corresponds to the peak price levels in the first and second quarters of 2008. The scenario of USD 500 per ton is considered as a low scenario for the future evolution of the price of MGO. The scenario using USD 750 per ton is the base scenario. There is a general feeling among market players that this price level is likely to materialize in the medium and long term. The scenario using USD 1,000 per ton is considered as a high scenario. While peaks above USD 1,000 per ton are very likely in the foreseeable future, we expect that the MGO price level will not reach an average price level of USD 1,000 per ton over longer periods of time (several years), at least in the medium term.

The share of bunker costs in total ship costs for a sample of 15 short sea liner services operated in the ECAs ranged between $26 \%$ and $48 \%$ in 2008 (Fig. 3). Total ship costs are the sum of bunker costs and vessel costs (i.e. the daily time charter rate for a vessel of that type and capacity). The share of fuel costs depends on the applicable bunker cost per ton: it will be high when fuel prices are high and lower when fuel prices are low. The average fuel cost for HFO $(1.5 \%)$ in 2008 amounted to USD 490 per ton, which is close to the high scenario (USD 556 per ton, see Table 1). The sample does not include fast short sea vessels with a commercial speed of 25 to 30 knots. For these vessels fuel costs are estimated to have reached between $38 \%$ and $60 \%$ in 2008 (based on data from market players).

Using the same sample of short sea services, we estimate the share of fuel costs in total ship costs for different scenarios regarding fuel price per ton (Table 2). For confidentiality reasons, the origin-destinations pairs are not listed in the table, only the service's sub-market and distance class. The results slightly

Table 1 Price per ton of HFO and MGO in the three scenarios

\begin{tabular}{lllllll}
\hline & HFO (1.5\%) & MGO (0.1\%) & HFO (1.5\%) & MGO (0.1\%) \\
Low & Base & Base & $\begin{array}{l}\text { HFO (1.5\%) } \\
\text { High }\end{array}$ & $\begin{array}{l}\text { MGO (0.1\%) } \\
\text { High }\end{array}$ \\
\hline USD & 278 & 500 & 417 & 750 & 556 & 1,000 \\
Euros & 193 & 348 & 290 & 521 & 386 & 695 \\
\hline
\end{tabular}




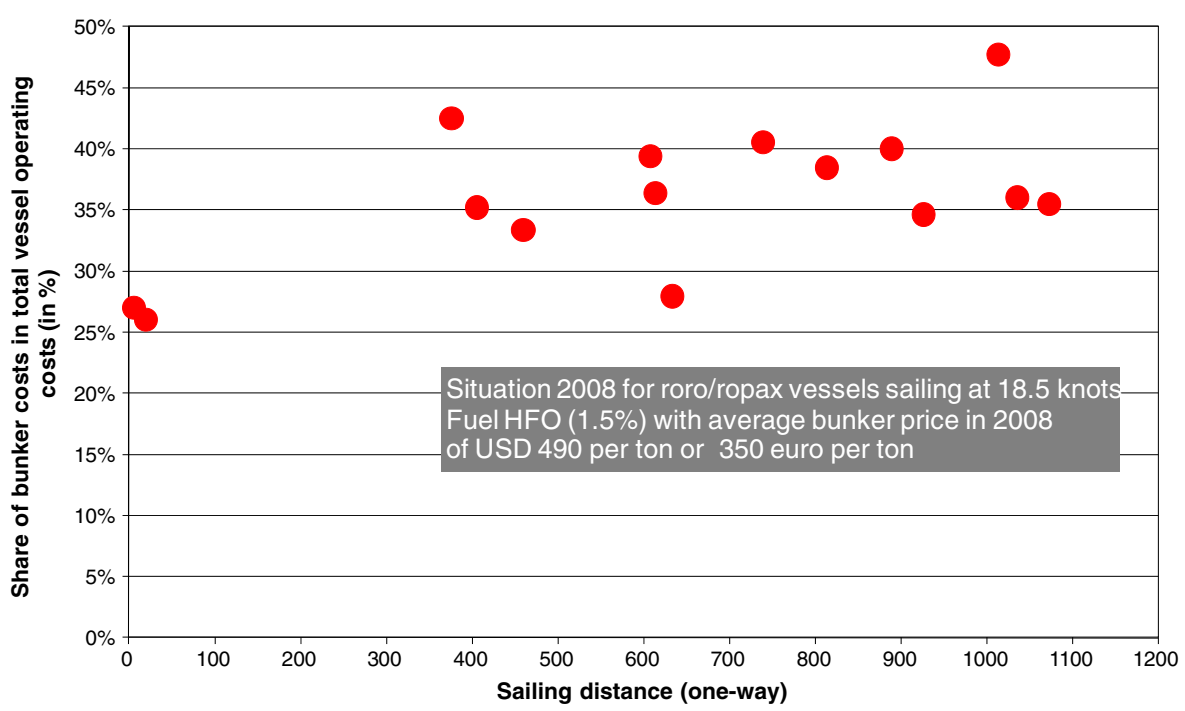

Fig. 3 Share of bunker costs in total ship costs (in \%) for a sample of liner services (source: own elaboration based on data provided by ship operators)

differ between services even in the same sub-market (see, e.g. routes 9 and 10). The differences are caused by a complex interaction between fleet composition, vessel capacities, vessel age and other operational characteristics of the observed services. When using HFO $(1.5 \%)$, the average share of bunkers in total ship costs amounts to $23.8 \%$ in the low scenario (with lower and upper limits $16.2 \%$ for ultrashort routes and $33.5 \%$, respectively), $31.9 \%$ in the base scenario (22.5\% to $43.1 \%$ ) and $38.3 \%$ in the high scenario ( $28 \%$ to $50 \%$ ). The use of MGO would increase the average share of fuel costs to $35.9 \%, 45.5 \%$ and $52.5 \%$, respectively. Table 3 provides an overview of the increase in total ship costs when shifting from HFO (1.5\%) to MGO. The impact on shipping lines' cost base would be considerable: a $25.5 \%$ increase in ship costs for the base scenario and even $30.6 \%$ on average for the high scenario with for a number of routes peaks of $40 \%$. These figures only relate to vessels with an average commercial speed of 18.5 knots. The average ship cost increase for fast short sea ships ( 25 to 30 knots on average) is estimated at $29 \%$ for the low scenario and even $40 \%$ (ranging from $31 \%$ to $47 \%$ ) for the high scenario.

\section{Impact of fuel cost increases on freight rates}

Ship operators will face higher vessel operating costs due to the use of low sulphur fuel. The short sea operator could in principle decide to absorb some of these additional costs, but such a strategy would negatively affect the financial base and attractiveness of the short sea business. The resulting lower margins would undermine innovation in the industry and would prolong the operating lifespan of (older) short sea vessels. Obsolete fleets are not attractive to 
Table 2 Share of bunker costs in total ship costs for the three scenarios and for two fuel types: HFO $(1.5 \%)$ and MGO (0.1\%) - short sea vessels with an average commercial speed of 18.5 knots (source: own elaboration based on data provided by ship operators)

\begin{tabular}{|c|c|c|c|c|c|c|c|c|}
\hline & \multirow[t]{3}{*}{ Sub-market } & \multirow[t]{3}{*}{$\begin{array}{l}\text { Distance } \\
\text { class }\end{array}$} & \multicolumn{6}{|c|}{$\begin{array}{l}\text { Share of bunker costs in total operating costs } \\
\text { (bunker + vessel costs) }\end{array}$} \\
\hline & & & $\begin{array}{l}\mathrm{HFO} \\
(1.5 \%)\end{array}$ & $\begin{array}{l}\text { MGO } \\
(0.1 \%)\end{array}$ & $\begin{array}{l}\mathrm{HFO} \\
(1.5 \%)\end{array}$ & $\begin{array}{l}\text { MGO } \\
(0.1 \%)\end{array}$ & $\begin{array}{l}\mathrm{HFO} \\
(1.5 \%)\end{array}$ & $\begin{array}{l}\text { MGO } \\
(0.1 \%)\end{array}$ \\
\hline & & & Low & Low & Base & Base & High & High \\
\hline Route 1 & UK/LH-H range $<->$ Baltic & $>750 \mathrm{~km}$ & $22.6 \%$ & $34.4 \%$ & $30.5 \%$ & $44.1 \%$ & $36.9 \%$ & $51.2 \%$ \\
\hline Route 2 & UK/LH-H range $<->$ Baltic & $>750 \mathrm{~km}$ & $23.3 \%$ & $35.3 \%$ & $31.3 \%$ & $45.1 \%$ & $37.8 \%$ & $52.2 \%$ \\
\hline Route 3 & $\mathrm{UK} / \mathrm{LH}-\mathrm{H}$ range $<->$ Baltic & $>750 \mathrm{~km}$ & $23.7 \%$ & $35.8 \%$ & $31.8 \%$ & $45.6 \%$ & $38.3 \%$ & $52.8 \%$ \\
\hline Route 4 & UK <-> LH-H range & $400-750 \mathrm{~km}$ & $29.0 \%$ & $42.3 \%$ & $38.0 \%$ & $52.4 \%$ & $44.9 \%$ & $59.5 \%$ \\
\hline Route 5 & $\mathrm{UK} / \mathrm{LH}-\mathrm{H}$ range $<->$ Baltic & $>750 \mathrm{~km}$ & $26.9 \%$ & $39.8 \%$ & $35.6 \%$ & $49.9 \%$ & $42.4 \%$ & $57.0 \%$ \\
\hline Route 6 & $\mathrm{UK} / \mathrm{LH}-\mathrm{H}$ range $<->$ Baltic & $400-750 \mathrm{~km}$ & $24.0 \%$ & $36.2 \%$ & $32.1 \%$ & $46.0 \%$ & $38.7 \%$ & $53.1 \%$ \\
\hline Route 7 & $\mathrm{UK} / \mathrm{LH}-\mathrm{H}$ range $<->$ Baltic & $400-750 \mathrm{~km}$ & $17.6 \%$ & $27.8 \%$ & $24.3 \%$ & $36.6 \%$ & $30.0 \%$ & $43.5 \%$ \\
\hline Route 8 & $\mathrm{UK} / \mathrm{LH}-\mathrm{H}$ range $<->$ Baltic & $400-750 \mathrm{~km}$ & $26.4 \%$ & $39.2 \%$ & $35.0 \%$ & $49.2 \%$ & $41.8 \%$ & $56.3 \%$ \\
\hline Route 9 & Intra-Baltic & $>750 \mathrm{~km}$ & $25.6 \%$ & $39.3 \%$ & $34.3 \%$ & $48.2 \%$ & $40.8 \%$ & $55.4 \%$ \\
\hline Route 10 & Intra-Baltic & $>750 \mathrm{~km}$ & $33.5 \%$ & $47.5 \%$ & $43.1 \%$ & $57.7 \%$ & $50.2 \%$ & $64.4 \%$ \\
\hline Route 11 & Intra-Baltic & $400-750 \mathrm{~km}$ & $23.0 \%$ & $35.0 \%$ & $31.0 \%$ & $44.7 \%$ & $37.4 \%$ & $51.9 \%$ \\
\hline Route 12 & Intra-Baltic & $400-750 \mathrm{~km}$ & $27.3 \%$ & $40.4 \%$ & $36.1 \%$ & $50.4 \%$ & $42.9 \%$ & $57.5 \%$ \\
\hline Route 13 & Intra-Baltic & $400-750 \mathrm{~km}$ & $21.6 \%$ & $33.2 \%$ & $29.3 \%$ & $42.7 \%$ & $35.5 \%$ & $49.8 \%$ \\
\hline Route 14 & Intra-Baltic & Ultra-short & $16.2 \%$ & $25.9 \%$ & $22.5 \%$ & $34.3 \%$ & $27.9 \%$ & $41.1 \%$ \\
\hline Route 15 & Intra-Baltic & Ultra-short & $16.9 \%$ & $26.9 \%$ & $23.5 \%$ & $35.5 \%$ & $39.0 \%$ & $42.3 \%$ \\
\hline \multicolumn{2}{|l|}{ Average } & & $23.8 \%$ & $35.9 \%$ & $31.9 \%$ & $45.5 \%$ & $38.5 \%$ & $52.5 \%$ \\
\hline \multicolumn{2}{|c|}{ Standard deviation } & & $4.6 \%$ & $5.9 \%$ & $5.6 \%$ & $6.4 \%$ & $6.1 \%$ & $6.5 \%$ \\
\hline \multicolumn{2}{|c|}{ High } & & $33.5 \%$ & $47.5 \%$ & $25.9 \%$ & $57.7 \%$ & $50.2 \%$ & $64.4 \%$ \\
\hline \multicolumn{2}{|l|}{ Low } & & $16.2 \%$ & $25.9 \%$ & $22.5 \%$ & $34.3 \%$ & $27.9 \%$ & $41.1 \%$ \\
\hline
\end{tabular}

$L H-H$ ports in the Le Havre-Hamburg range, a port range containing all seaports along the coastline between Hamburg in Germany and Le Havre in France

customers, so volume losses are not unthinkable under this scenario. A more logical strategy for short sea operators is to charge their customers to recuperate the additional fuel costs linked to the use of low sulphur fuel. The price of short sea services will therefore increase with the applicable price increases depending on the price scenario for MGO. This section analyses the impact of ship cost increases (as a result of the use of MGO) on freight rates. Ship costs do not include all costs related to running a short sea service. This makes cost increases in percent connected to the shift from the use of HFO to MGO do not necessarily lead to the same increase in freight rates.

Table 4 summarizes the share of fuel costs in the total freight rate per unit for a sample of 16 routes with vessels sailing at 18.5 knots on average and one route with a fast ship sailing at 25 knots. The freight rate is defined here as the total unit price customers pay for using the short sea service (typically per 17 lane meters- 
Table 3 Increase in total ship costs as a result of the use of MGO (0.1\%) - short sea vessels with an average commercial speed of 18.5 knots (source: own elaboration based on data provided by ship operators)

\begin{tabular}{|c|c|c|c|c|c|}
\hline & \multirow[t]{3}{*}{ Sub-market } & \multirow[t]{3}{*}{ Distance class } & \multicolumn{3}{|c|}{ Total costs increase per trip (in \%) } \\
\hline & & & \multicolumn{3}{|c|}{ Scenario } \\
\hline & & & Low & Base & High \\
\hline Route 1 & $\mathrm{UK} / \mathrm{LH}-\mathrm{H}$ range $<_{-}>$Baltic & $>750 \mathrm{~km}$ & $18.1 \%$ & $24.4 \%$ & $29.5 \%$ \\
\hline Route 2 & UK/LH-H range $<->$ Baltic & $>750 \mathrm{~km}$ & $18.6 \%$ & $25.0 \%$ & $30.2 \%$ \\
\hline Route 3 & $\mathrm{UK} / \mathrm{LH}-\mathrm{H}$ range $<->$ Baltic & $>750 \mathrm{~km}$ & $18.9 \%$ & $25.4 \%$ & $30.2 \%$ \\
\hline Route 4 & $\mathrm{UK}<->\mathrm{LH}-\mathrm{H}$ range & $400-750 \mathrm{~km}$ & $23.2 \%$ & $30.4 \%$ & $35.9 \%$ \\
\hline Route 5 & $\mathrm{UK} / \mathrm{LH}-\mathrm{H}$ range $<_{-}>$Baltic & $>750 \mathrm{~km}$ & $21.5 \%$ & $28.5 \%$ & $33.9 \%$ \\
\hline Route 6 & $\mathrm{UK} / \mathrm{LH}-\mathrm{H}$ range $<_{-}>$Baltic & $400-750 \mathrm{~km}$ & $19.2 \%$ & $25.7 \%$ & $30.9 \%$ \\
\hline Route 7 & $\mathrm{UK} / \mathrm{LH}-\mathrm{H}$ range $<_{-}>$Baltic & $400-750 \mathrm{~km}$ & $14.1 \%$ & $19.5 \%$ & $24.0 \%$ \\
\hline Route 8 & UK/LH-H range $<->$ Baltic & $400-750 \mathrm{~km}$ & $21.1 \%$ & $28.0 \%$ & $33.4 \%$ \\
\hline Route 9 & Intra-Baltic & $>750 \mathrm{~km}$ & $20.5 \%$ & $27.3 \%$ & $32.6 \%$ \\
\hline Route 10 & Intra-Baltic & $>750 \mathrm{~km}$ & $26.8 \%$ & $34.5 \%$ & $40.1 \%$ \\
\hline Route 11 & Intra-Baltic & $400-750 \mathrm{~km}$ & $18.4 \%$ & $24.8 \%$ & $30.0 \%$ \\
\hline Route 12 & Intra-Baltic & $400-750 \mathrm{~km}$ & $21.9 \%$ & $28.9 \%$ & $34.3 \%$ \\
\hline Route 13 & Intra-Baltic & $400-750 \mathrm{~km}$ & $17.3 \%$ & $23.4 \%$ & $28.4 \%$ \\
\hline Route 14 & Intra-Baltic & Ultra-short & $13.0 \%$ & $18.0 \%$ & $22.3 \%$ \\
\hline Route 15 & Intra-Baltic & Ultra-short & $13.6 \%$ & $18.8 \%$ & $23.2 \%$ \\
\hline \multicolumn{2}{|l|}{ Average } & & $19.1 \%$ & $25.5 \%$ & $30.6 \%$ \\
\hline \multicolumn{2}{|c|}{ Standard deviation } & & $3.7 \%$ & $4.5 \%$ & $4.9 \%$ \\
\hline \multicolumn{2}{|c|}{ High } & & $26.8 \%$ & $34.5 \%$ & $40.1 \%$ \\
\hline \multicolumn{2}{|l|}{ Low } & & $13.0 \%$ & $18.0 \%$ & $22.3 \%$ \\
\hline
\end{tabular}

equivalent to a truck/trailer combination). The bunker costs are no longer expressed in euros per kilometer per unit capacity (which was the basis for the calculations related to the share of bunker costs in total ship costs), but in euros per kilometer per shipped unit. Data on the average utilization degree of the vessels operating on the 17 routes were obtained from short sea operators. The average utilization degree of the vessels in 2008 reached $70 \%$ with a lowest value of $59.2 \%$ and a highest value of $83.5 \%$. However, 2008 was considered a very good year in terms of utilization degrees and the sample did not include short routes. Based on discussions with shipping lines, we therefore adjusted the average figures to $40 \%$ utilization for ultrashort routes $(<50 \mathrm{~km}), 55 \%$ for short routes $(50-125 \mathrm{~km}), 60 \%$ for medium long routes $(125-400 \mathrm{~km})$ and $75 \%$ for long routes $(>400 \mathrm{~km})$. We are aware that some shipping lines use fuel surcharges on top of the base freight rate to charge for (part of) the bunker costs. The freight rate used in this exercise includes all surcharges (booking fees, fuel surcharges, etc.). The bunker costs represent an important component in the total freight rate. When fuel prices for HFO are high (high scenario), its share in the freight rate typically reaches $20 \%$ to $25 \%$, with peaks up to 
Table 4 Share of bunker costs in total freight rate per unit for the three scenarios and for two fuel types: HFO (1.5\%) and MGO (0.1\%) — short sea vessels with an average commercial speed of 18.5 knots, except route 17 (fast ship; source: own calculations based on data provided by ship operators)

\begin{tabular}{|c|c|c|c|c|c|c|c|c|}
\hline & \multirow[t]{3}{*}{ Sub-market } & \multirow{3}{*}{$\begin{array}{l}\text { Distance } \\
\text { class }\end{array}$} & \multicolumn{6}{|c|}{ Share of bunker costs in total freight rate } \\
\hline & & & $\begin{array}{l}\text { HFO } \\
(1.5 \%)\end{array}$ & $\begin{array}{l}\text { MGO } \\
(0.1 \%)\end{array}$ & $\begin{array}{l}\text { HFO } \\
(1.5 \%)\end{array}$ & $\begin{array}{l}\text { MGO } \\
(0.1 \%)\end{array}$ & $\begin{array}{l}\text { HFO } \\
(1.5 \%)\end{array}$ & $\begin{array}{l}\text { MGO } \\
(0.1 \%)\end{array}$ \\
\hline & & & Low & & Base & & High & \\
\hline Route 1 & UK/LH-H range $<->$ Baltic & $>750 \mathrm{~km}$ & $8.9 \%$ & $14.9 \%$ & $12.8 \%$ & $20.8 \%$ & $16.3 \%$ & $25.9 \%$ \\
\hline Route 2 & $\mathrm{UK} / \mathrm{LH}-\mathrm{H}$ range $<->$ Baltic & $>750 \mathrm{~km}$ & $15.5 \%$ & $24.9 \%$ & $21.6 \%$ & $33.2 \%$ & $26.9 \%$ & $39.8 \%$ \\
\hline Route 3 & UK/LH-H range $<->$ Baltic & $>750 \mathrm{~km}$ & $9.9 \%$ & $16.6 \%$ & $14.2 \%$ & $23.0 \%$ & $18.1 \%$ & $28.4 \%$ \\
\hline Route 4 & UK <-> LH-H range & $400-750 \mathrm{~km}$ & $10.3 \%$ & $17.1 \%$ & $14.7 \%$ & $23.6 \%$ & $18.6 \%$ & $29.2 \%$ \\
\hline Route 5 & $\mathrm{UK} / \mathrm{LH}-\mathrm{H}$ range $<->$ Baltic & $>750 \mathrm{~km}$ & $9.5 \%$ & $15.9 \%$ & $13.6 \%$ & $22.1 \%$ & $17.4 \%$ & $27.4 \%$ \\
\hline Route 6 & $\mathrm{UK} / \mathrm{LH}-\mathrm{H}$ range $<->$ Baltic & $400-750 \mathrm{~km}$ & $8.8 \%$ & $14.7 \%$ & $12.6 \%$ & $20.6 \%$ & $16.1 \%$ & $25.7 \%$ \\
\hline Route 7 & UK/LH-H range $<->$ Baltic & $400-750 \mathrm{~km}$ & $15.5 \%$ & $24.9 \%$ & $21.6 \%$ & $33.2 \%$ & $26.9 \%$ & $39.8 \%$ \\
\hline Route 8 & $\mathrm{UK} / \mathrm{LH}-\mathrm{H}$ range $<->$ Baltic & $400-750 \mathrm{~km}$ & $10.2 \%$ & $17.0 \%$ & $14.6 \%$ & $23.5 \%$ & $18.5 \%$ & $29.1 \%$ \\
\hline Route 9 & Intra-Baltic & $>750 \mathrm{~km}$ & $11.1 \%$ & $18.4 \%$ & $15.8 \%$ & $25.3 \%$ & $20.0 \%$ & $31.1 \%$ \\
\hline Route 10 & Intra-Baltic & $>750 \mathrm{~km}$ & $23.4 \%$ & $35.4 \%$ & $31.4 \%$ & $45.2 \%$ & $37.9 \%$ & $52.3 \%$ \\
\hline Route 11 & Intra-Baltic & $400-750 \mathrm{~km}$ & $13.4 \%$ & $21.7 \%$ & $18.8 \%$ & $29.4 \%$ & $23.6 \%$ & $35.7 \%$ \\
\hline Route 12 & Intra-Baltic & $400-750 \mathrm{~km}$ & $14.7 \%$ & $23.7 \%$ & $20.6 \%$ & $31.8 \%$ & $25.6 \%$ & $38.3 \%$ \\
\hline Route 13 & Intra-Baltic & $400-750 \mathrm{~km}$ & $15.1 \%$ & $24.2 \%$ & $21.1 \%$ & $32.4 \%$ & $26.2 \%$ & $39.0 \%$ \\
\hline Route 14 & Intra-Baltic & $125-400 \mathrm{~km}$ & $11.1 \%$ & $18.3 \%$ & $15.8 \%$ & $25.2 \%$ & $19.9 \%$ & $30.9 \%$ \\
\hline Route 15 & Intra-Baltic & $125-400 \mathrm{~km}$ & $12.9 \%$ & $21.0 \%$ & $18.2 \%$ & $28.6 \%$ & $22.8 \%$ & $34.8 \%$ \\
\hline Route 16 & Intra-Baltic & $>750 \mathrm{~km}$ & $20.6 \%$ & $31.8 \%$ & $28.0 \%$ & $41.2 \%$ & $34.1 \%$ & $48.3 \%$ \\
\hline Route 17 & Intra-Baltic (fast ship $25 \mathrm{kn}$ ) & $>750 \mathrm{~km}$ & $32.9 \%$ & $46.9 \%$ & $42.5 \%$ & $57.0 \%$ & $49.5 \%$ & $63.9 \%$ \\
\hline Average & & & $14.3 \%$ & $22.8 \%$ & $19.9 \%$ & $30.4 \%$ & $24.6 \%$ & $36.4 \%$ \\
\hline High & & & $32.9 \%$ & $46.9 \%$ & $42.5 \%$ & $57.0 \%$ & $49.5 \%$ & $63.9 \%$ \\
\hline Low & & & $8.8 \%$ & $14.7 \%$ & $12.6 \%$ & $20.6 \%$ & $16.1 \%$ & $25.7 \%$ \\
\hline
\end{tabular}

$50 \%$ for fast vessels. A shift to the use of MGO would in such a case lift the bunker share to a level of $35 \%$ to $40 \%$ with peaks up to an elevated level of $64 \%$ for fast vessels.

Table 5 summarizes the implications of a shift from HFO (1.5\%) to MGO $(0.1 \%)$. While large differences can be observed among the 17 routes in the sample, the impact on the freight rate is considerable in all scenarios. For traditional short sea services, freight rate increases are estimated to reach $8 \%$ to $13 \%$ for the low scenario and around $20 \%$ for the high scenario. For fast short sea services, the figures are much higher: on average, $25 \%$ for the low scenario and $40 \%$ for the high scenario. It must be stressed that all of the above figures are averages and that quite substantial differences might occur among the different liner services. In the next section, a comparative price model is developed to analyse the impact of these freight rate increases on modal competition for a set of origin-destination routes. 
Table 5 Expected minimal increase in freight rates per unit as a result of the use of MGO (0.1\%) - short sea vessels with an average commercial speed of 18.5 knots, except route 17 (fast ship; source: own calculations based on data provided by ship operators)

\begin{tabular}{|c|c|c|c|c|c|}
\hline & \multirow[t]{3}{*}{ Sub-market } & \multirow[t]{3}{*}{ Distance class } & \multicolumn{3}{|c|}{ Total increase in freight rate per trip (in \%) } \\
\hline & & & \multicolumn{3}{|c|}{ Scenario } \\
\hline & & & Low & Base & High \\
\hline Route 1 & $\mathrm{UK} / \mathrm{LH}-\mathrm{H}$ range $<->$ Baltic & $>750 \mathrm{~km}$ & $7.1 \%$ & $10.2 \%$ & $13.0 \%$ \\
\hline Route 2 & $\mathrm{UK} / \mathrm{LH}-\mathrm{H}$ range $<->$ Baltic & $>750 \mathrm{~km}$ & $12.4 \%$ & $17.3 \%$ & $21.5 \%$ \\
\hline Route 3 & UK/LH-H range $<->$ Baltic & $>750 \mathrm{~km}$ & $7.9 \%$ & $11.4 \%$ & $14.5 \%$ \\
\hline Route 4 & UK <-> LH-H range & $400-750 \mathrm{~km}$ & $8.2 \%$ & $11.7 \%$ & $14.9 \%$ \\
\hline Route 5 & UK/LH-H range $<->$ Baltic & $>750 \mathrm{~km}$ & $7.6 \%$ & $10.9 \%$ & $13.9 \%$ \\
\hline Route 6 & $\mathrm{UK} / \mathrm{LH}-\mathrm{H}$ range $<->$ Baltic & $400-750 \mathrm{~km}$ & $7.0 \%$ & $10.1 \%$ & $12.9 \%$ \\
\hline Route 7 & $\mathrm{UK} / \mathrm{LH}-\mathrm{H}$ range $<->$ Baltic & $400-750 \mathrm{~km}$ & $12.4 \%$ & $17.3 \%$ & $21.5 \%$ \\
\hline Route 8 & UK/LH-H range $<->$ Baltic & $400-750 \mathrm{~km}$ & $8.2 \%$ & $11.7 \%$ & $14.8 \%$ \\
\hline Route 9 & Intra-Baltic & $>750 \mathrm{~km}$ & $8.9 \%$ & $12.7 \%$ & $16.0 \%$ \\
\hline Route 10 & Intra-Baltic & $>750 \mathrm{~km}$ & $18.7 \%$ & $25.1 \%$ & $30.3 \%$ \\
\hline Route 11 & Intra-Baltic & $400-750 \mathrm{~km}$ & $10.7 \%$ & $15.0 \%$ & $18.8 \%$ \\
\hline Route 12 & Intra-Baltic & $400-750 \mathrm{~km}$ & $11.8 \%$ & $16.5 \%$ & $20.5 \%$ \\
\hline Route 13 & Intra-Baltic & $400-750 \mathrm{~km}$ & $12.1 \%$ & $16.9 \%$ & $21.0 \%$ \\
\hline Route 14 & Intra-Baltic & $125-400 \mathrm{~km}$ & $8.9 \%$ & $12.6 \%$ & $15.9 \%$ \\
\hline Route 15 & Intra-Baltic & $125-400 \mathrm{~km}$ & $10.3 \%$ & $14.6 \%$ & $18.3 \%$ \\
\hline Route 16 & Intra-Baltic & $>750 \mathrm{~km}$ & $16.5 \%$ & $22.4 \%$ & $27.3 \%$ \\
\hline Route 17 & Intra-Baltic (fast ship $25 \mathrm{kn}$ ) & $>750 \mathrm{~km}$ & $26.3 \%$ & $34.0 \%$ & $39.6 \%$ \\
\hline Average & & & $11.5 \%$ & $15.9 \%$ & $19.7 \%$ \\
\hline High & & & $26.3 \%$ & $34.0 \%$ & $39.6 \%$ \\
\hline Low & & & $7.0 \%$ & $10.1 \%$ & $12.9 \%$ \\
\hline
\end{tabular}

\section{Comparative price analysis on origin-destination pairs}

\subsection{Model specification}

The remainder of the paper focuses on the second research question: what is the expected impact of the new requirements of IMO on the competitiveness of roro shipping in the ECAs compared to other transport modes (trucking in particular)? In view of answering this question, we first develop a detailed price analysis to assess modal competition between the roro/truck option and the 'truck only' option on 30 origin-destination routes linked to the ECAs. The 'truck only' option means that a truck is used all the way from origin to destination without including a short sea section. The 30 origin-destination pairs are centered around four short sea routes: (1) Germany/Denmark to Sweden, (2) the English Channel, (3) West Europe to Baltic States, and (4) West Europe to Scandinavia (Sweden/Norway). Different short sea service routes can be considered per origin-destination pair as shown in Figs. 4 and 5. 


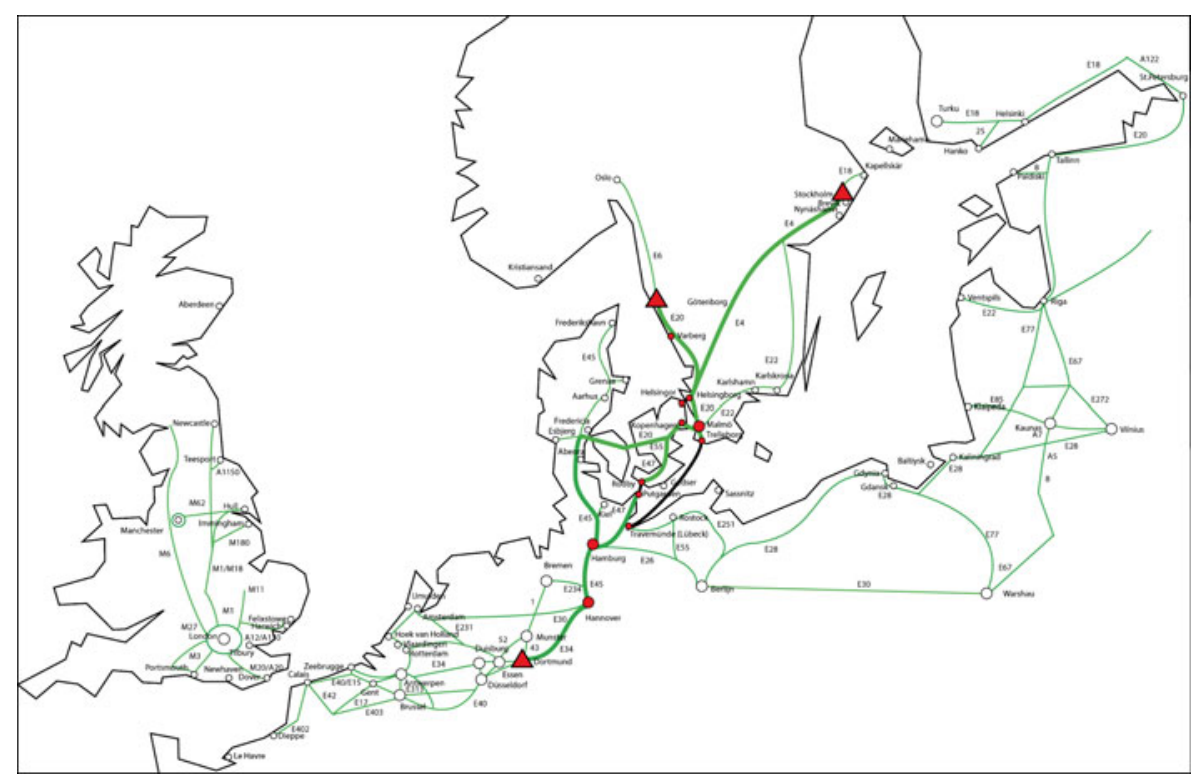

Fig. 4 Geographical representation of routes between Germany/Denmark to Sweden

All these short sea solutions face potential competition from a 'truck only' option (for Dover-Calais in combination with the Channel Tunnel). The Baltic States can be reached from Western Europe by following the highways and main roads connecting Germany, Poland and the eastern Baltic.

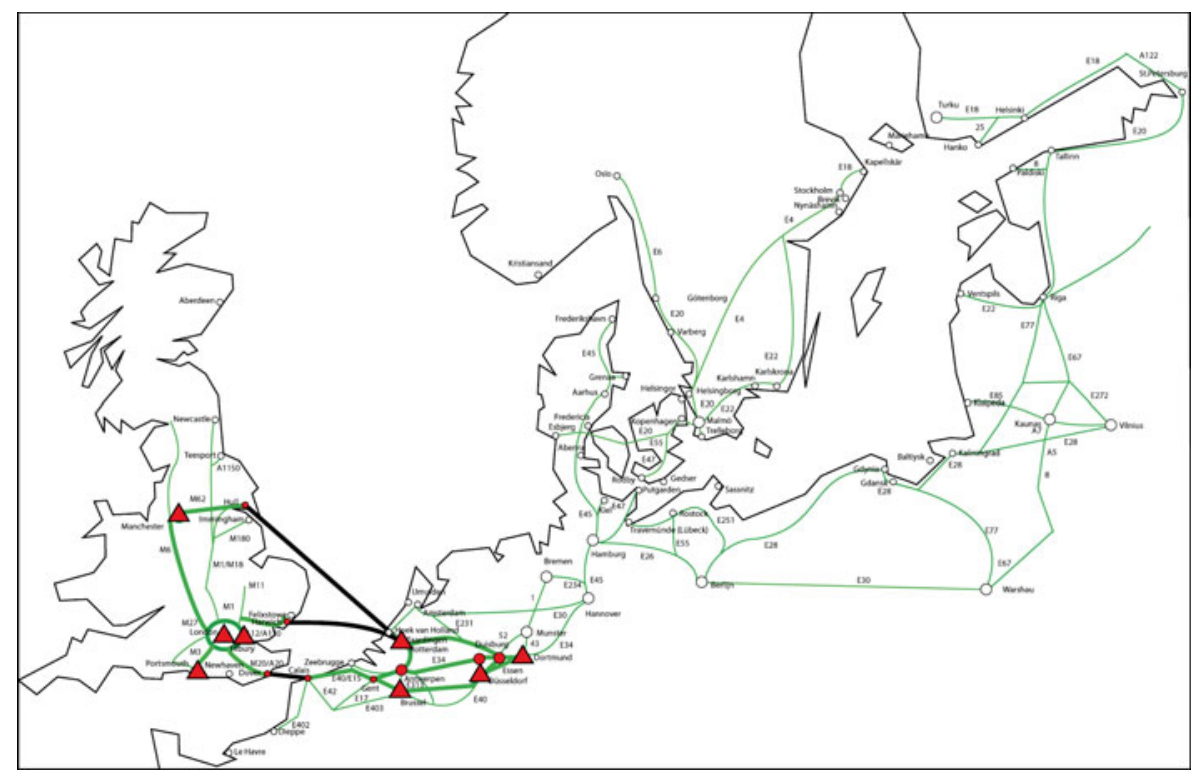

Fig. 5 Geographical representation of routes on the English Channel 
The price model used in this section takes the following simple form:

$$
P_{\mathrm{r}}=p_{\mathrm{T}} \times D_{\mathrm{T}}+p_{\mathrm{R}} \times D_{\mathrm{R}}+P_{\mathrm{F}}
$$

with:

$P_{\mathrm{r}} \quad$ Total price per truckload for origin-destination route $\mathrm{r}$

$P_{\mathrm{F}} \quad$ One-way price for fixed crossing F, if any (e.g. Channel Tunnel, Fernbelt, Öresund)

$p_{\mathrm{T}} \quad$ Price per vehicle-km (truck) for truck distance $D_{\mathrm{T}}$

$p_{\mathrm{R}} \quad$ Price per vessel-km per 17 lane meter (truck equivalent) for nautical distance $D_{\mathrm{R}}$

\subsection{Distances $D_{\mathrm{T}}$ and $D_{\mathrm{R}}$}

The road distances $D_{\mathrm{T}}$ were obtained through the use of a route planner. The sailing distances $D_{\mathrm{R}}$ for short sea vessels are based on the maritime distance calculator available at Dataloy (www.dataloy.com). The distances per origin-destination relations are presented in Table 6 and 7. For the highways, the average driving speed is set at $80 \mathrm{~km} / \mathrm{h}$, for other roads $65 \mathrm{~km} / \mathrm{h}$. The commercial speed of roro/ ropax vessels in this analysis amounts to $18.5 \mathrm{knots}(34.3 \mathrm{~km} / \mathrm{h})$.

\subsection{Prices for fixed links $P_{\mathrm{F}}$}

Price factor $P_{\mathrm{F}}$ reflects that trucks might be confronted with additional costs when using fixed links. On the English Channel, ferries face stiff competition from the Eurotunnel for manned truck/trailer combinations. In 2008, Eurotunnel has transported 1.25 million trucks on its shuttles between Folkestone and Calais, i.e. the equivalent of 14.2 million tons of goods. The shuttles dedicated to trucks can transport up to 30 trucks in semi-enclosed wagons. Trucks cross the Straits in $90 \mathrm{~min}$ at the most, from the M20 motorway in the UK to the A16 motorway in France, including time for border controls, loading, crossing and unloading. Truck shuttles leave every 10, 12 or 15 min depending on traffic levels, and drivers do not need to book ahead. The flexible timetables are adjusted to traffic levels every day. The tariff for a truck of 13-15 m is about 300-350 euros excluding VAT (one way, excluding discounts, online booking system; www.eurotunnel.com). Eurotunnel's current strategy is to run fewer freight shuttles than previously, but to run them full. They do this by offering very competitive rates to large hauliers, but under very restrictive terms - a very good price for pre-booked slots on nominated shuttles, but punitively high charges for spot bookings (or last minute changes). This strategy enables Eurotunnel to control its operating costs, but at the expense of offering low flexibility to its customers. The ferries, by contrast, offer more flexibility ('turn up and go when you want').

The fixed links in Denmark (Great Belt Link and Oresund Link) make it possible for truck drivers to drive from the European mainland to Sweden and Norway. The use of these fixed links is not free of charge. The full price for a truck/trailer combination is 109 euros including VAT or 85.7 euros excluding VAT (one way). Discounts apply to most of the trucking companies frequently using the connection 
Table 6 Origin-destination relations considered in the comparative price analysis - in km Part 1

\begin{tabular}{|c|c|c|c|c|c|c|}
\hline \multirow[t]{2}{*}{ Distances } & \multicolumn{2}{|c|}{ Alternative 1 (truck only) } & \multicolumn{4}{|c|}{ Alternative 2 (truck/shortsea) } \\
\hline & $\begin{array}{l}\text { Truck } \\
\text { total }(\mathrm{km})\end{array}$ & Rail (km) & $\begin{array}{l}\text { Truck } \\
\text { (pre) (km) }\end{array}$ & Shortsea $(\mathrm{km})$ & $\begin{array}{l}\text { Truck } \\
\text { (post) km }\end{array}$ & $\begin{array}{l}\text { Truck } \\
\text { (total) } \mathrm{km}\end{array}$ \\
\hline \multicolumn{3}{|l|}{ Germany/Denmark to Sweden } & \multicolumn{4}{|c|}{ via Travemünde-Trelleburg } \\
\hline 1.1. Dortmond-Göteborg & $113(\mathrm{~F}+\mathrm{O})$ & 0 & 421 & 224 & 303 & 724 \\
\hline 1.2. Dortund-Stockholm & $1499(\mathrm{~F}+\mathrm{O})$ & 0 & 421 & 224 & 646 & 1067 \\
\hline \multicolumn{2}{|l|}{ English Channel } & via Chunnel & \multicolumn{4}{|c|}{ via Calais-Dover } \\
\hline 2.1. Rotterdam-Tilbury & 428 & 40 & 312 & 43 & 116 & 428 \\
\hline 2.2. Rotterdam-London & 452 & 40 & 312 & 43 & 140 & 452 \\
\hline 2.3. Rotterdam-Portsmouth & 538 & 40 & 312 & 43 & 226 & 538 \\
\hline 2.4. Düsseldorf-Tilbury & 515 & 40 & 401 & 43 & 116 & 517 \\
\hline 2.5. Düsseldorf-London & 540 & 40 & 401 & 43 & 140 & 541 \\
\hline 2.6. Düsseldorf-Portsmouth & 626 & 40 & 401 & 43 & 226 & 627 \\
\hline 2.7. Brussels-Tilbury & 315 & 40 & 201 & 43 & 116 & 317 \\
\hline 2.8. Brussels-London & 340 & 40 & 201 & 43 & 140 & 341 \\
\hline 2.9. Brussels-Portsmouth & 426 & 40 & 201 & 43 & 226 & 427 \\
\hline 2.10. Dortmund-Tilbury & 557 & 40 & 442 & 43 & 116 & 558 \\
\hline 2.11. Dortmund-London & 582 & 40 & 442 & 43 & 140 & 582 \\
\hline 2.12. Dortmund-Portsmouth & 668 & 40 & 442 & 43 & 226 & 668 \\
\hline 2.13. Rotterdam-Manchester & 787 & 40 & 312 & 43 & 475 & 787 \\
\hline 2.14. Düsseldorf-Manchester & 876 & 40 & 401 & 43 & 475 & 876 \\
\hline 2.15. Brussels-Manchester & 676 & 40 & 201 & 43 & 475 & 676 \\
\hline 2.16. Dortmund-Manchester & 917 & 40 & 442 & 43 & 475 & 917 \\
\hline \multicolumn{3}{|l|}{ West Europe-Baltic States } & \multicolumn{4}{|c|}{ via Lübeck-Riga } \\
\hline 3.1. Dieppe-Tallinn & 2458 & 0 & 1006 & 1011 & 309 & 1315 \\
\hline 3.2. Dieppe-Kaunas & 1845 & 0 & 1006 & 1011 & 264 & 1270 \\
\hline 3.3. Antwerpen-Tallinn & 2236 & 0 & 636 & 1011 & 309 & 945 \\
\hline 3.4. Antwerpen-Kaunas & 1669 & 0 & 636 & 1011 & 264 & 900 \\
\hline 3.5. Amsterdam-Tallinn & 2171 & 0 & 642 & 1011 & 309 & 951 \\
\hline 3.6. Amsterdam-Kaunas & 1604 & 0 & 642 & 1011 & 264 & 906 \\
\hline 3.7. Hamburg-Tallinn & 1830 & 0 & 67 & 1011 & 309 & 376 \\
\hline 3.8. Hamburg-Kaunas & 1263 & 0 & 67 & 1011 & 264 & 331 \\
\hline 3.9. Esbjerg-Tallinn & 2128 & 0 & 374 & 1011 & 309 & 683 \\
\hline 3.10. Esjberg-Kaunas & 1561 & 0 & 374 & 1011 & 264 & 638 \\
\hline \multicolumn{3}{|l|}{ West Europe-Scandinavia } & \multicolumn{4}{|c|}{ via Ghent-Göteborg } \\
\hline 4.1. Rotterdam-Oslo & $1554(\mathrm{~F}+\mathrm{O})$ & 0 & 157 & 1083 & 294 & 451 \\
\hline 4.2. Rotterdam-Stockholm & $1606(\mathrm{~F}+\mathrm{O}$ & 0 & 157 & 1083 & 469 & 626 \\
\hline
\end{tabular}

'Chunnel' stands for Channel Tunnel

a $20 \mathrm{~km}$ for Putgarten-Rödby and $6 \mathrm{~km}$ for Helsingör-Helsingborg

${ }^{\mathrm{b}}$ Of which $198 \mathrm{~km}$ between Rödby and Helsingör

$(\mathrm{O})=$ via Öresund-link

$(\mathrm{F}+\mathrm{O})=$ via Great Belt and Öresund-link 
Table 7 Origin-destination relations considered in the comparative price analysis - in km Part 2

\begin{tabular}{|c|c|c|c|c|c|c|c|c|}
\hline \multirow[t]{2}{*}{ Distances } & \multicolumn{4}{|c|}{ Alternative 3 (truck/shortsea) } & \multicolumn{4}{|c|}{ Alternative 4 (truck/shortsea) } \\
\hline & $\begin{array}{l}\text { Truck } \\
\text { (pre) } \mathrm{km}\end{array}$ & $\begin{array}{l}\text { Shortsea } \\
(\mathrm{km})\end{array}$ & $\begin{array}{l}\text { Truck } \\
\text { (post) } \mathrm{km}\end{array}$ & $\begin{array}{l}\text { Truck } \\
\text { (total) } \mathrm{km}\end{array}$ & $\begin{array}{l}\text { Truck } \\
\text { (pre) }(\mathrm{km})\end{array}$ & $\begin{array}{l}\text { Shortsea } \\
(\mathrm{km})\end{array}$ & $\begin{array}{l}\text { Truck } \\
\text { (post) km }\end{array}$ & $\begin{array}{l}\text { Truck } \\
\text { (total) } \mathrm{km}\end{array}$ \\
\hline Germany/Denmark to Sweden & \multicolumn{4}{|c|}{ via Putgarten-Rödby and Oresund } & \multicolumn{4}{|c|}{$\begin{array}{l}\text { via Putgarten-Rödby and } \\
\text { Helsingör-Helsingborg }\end{array}$} \\
\hline 1.1. Dortmond-Göteborg & 681 & 20 & $461(\mathrm{O})$ & 1142 & 681 & 26 & 411 & 1092 \\
\hline 1.2. Dortund-Stockholm & 681 & 20 & $805(\mathrm{O})$ & 1468 & 681 & $26^{\mathrm{a}}$ & $755^{\mathrm{b}}$ & 1436 \\
\hline English Channel & \multicolumn{4}{|c|}{ via Rotterdam-Harwich } & \multicolumn{4}{|c|}{ via Rotterdam-Hull } \\
\hline 2.1. Rotterdam-Tilbury & 30 & 204 & 109 & 139 & - & - & - & - \\
\hline 2.2. Rotterdam-London & 30 & 204 & 128 & 158 & - & - & - & - \\
\hline 2.3. Rotterdam-Portsmouth & 30 & 204 & 263 & 239 & - & - & - & - \\
\hline 2.4. Düsseldorf-Tilbury & 260 & 204 & 109 & 369 & - & - & - & - \\
\hline 2.5. Düsseldorf-London & 260 & 204 & 1428 & 388 & - & - & - & - \\
\hline 2.6. Düsseldorf-Portsmouth & 260 & 204 & 263 & 523 & - & - & - & - \\
\hline 2.7. Brussels-Tilbury & 179 & 204 & 109 & 288 & - & - & - & - \\
\hline 2.8. Brussels-London & 179 & 204 & 128 & 307 & - & - & - & - \\
\hline 2.9. Brussels-Portsmouth & 179 & 204 & 263 & 442 & - & - & - & - \\
\hline 2.10. Dortmund-Tilbury & 279 & 204 & 109 & 388 & - & - & - & - \\
\hline 2.11. Dortmund-London & 279 & 204 & 128 & 407 & - & - & - & - \\
\hline 2.12. Dortmund-Portsmouth & 279 & 204 & 263 & 542 & - & - & - & - \\
\hline 2.13. Rotterdam-Manchester & 30 & 204 & 400 & 430 & 30 & 335 & 154 & 184 \\
\hline 2.14. Düsseldorf-Manchester & 260 & 204 & 400 & 660 & 260 & 335 & 154 & 414 \\
\hline 2.15. Brussels-Manchester & 179 & 204 & 400 & 579 & 179 & 335 & 154 & 333 \\
\hline 2.16. Dortmund-Manchester & 279 & 204 & 400 & 679 & 279 & 335 & 154 & 433 \\
\hline West Europe-Baltic States & \multicolumn{4}{|c|}{ via Kappelskär-Paldiski } & \multicolumn{4}{|c|}{ Via Karlshamn-Klaipeda } \\
\hline 3.1. Dieppe-Tallinn & - & - & - & - & - & - & - & - \\
\hline 3.2. Dieppe-Kaunas & - & - & - & - & - & - & - & - \\
\hline 3.3. Antwerpen-Tallinn & - & - & - & - & - & - & - & - \\
\hline 3.4. Antwerpen-Kaunas & - & - & - & - & - & - & - & - \\
\hline 3.5. Amsterdam-Tallinn & - & - & - & - & - & - & - & - \\
\hline 3.6. Amsterdam-Kaunas & - & - & - & - & - & - & - & - \\
\hline 3.7. Hamburg-Tallinn & - & - & - & - & - & - & - & - \\
\hline 3.8. Hamburg-Kaunas & - & - & - & - & - & - & - & - \\
\hline 3.9. Esbjerg-Tallinn & $1030(\mathrm{~F}+\mathrm{O})$ & 296 & 51 & 1081 & - & - & - & - \\
\hline 3.10. Esjberg-Kaunas & - & - & - & - & $483(\mathrm{~F}+\mathrm{O})$ & 413 & 215 & 696 \\
\hline West Europe-Scandinavia & \multicolumn{4}{|c|}{ via Travemünde-Trelleborg } & \multicolumn{4}{|c|}{ via Putgarten-Rödby } \\
\hline 4.1. Rotterdam-Oslo & 577 & 224 & 597 & 1174 & 835 & 20 & $756(\mathrm{O})$ & 1591 \\
\hline 4.2. Rotterdam-Stockholm & 577 & 224 & 646 & 1223 & 835 & 20 & $805(\mathrm{O})$ & 1640 \\
\hline
\end{tabular}

'Chunnel' stands for Channel Tunnel

a $20 \mathrm{~km}$ for Putgarten-Rödby and $6 \mathrm{~km}$ for Helsingör-Helsingborg

${ }^{\mathrm{b}}$ Of which $198 \mathrm{~km}$ between Rödby and Helsingör

$(\mathrm{O})=$ via Öresund-link

$(\mathrm{F}+\mathrm{O})=$ via Great Belt and Öresund-link 
(3.3\% for $500-5,000$ crossings and $6.4 \%$ for $5,000-10,000$ crossings per year, see www.oresundsbron.com). In our analysis, we use 85 euros as a base rate for trucks passed on to the customer. There has been criticism of the tolls that are much higher than many consider reasonable for a bridge. However, they are compatible with the ferry charges that were levied before the bridge was built and for the ferries still running between Helsingborg-Helsingør. For example, Scandlines charges 113 euros for a truck of $13 \mathrm{~m}$ and 139 euros for a truck up to $19 \mathrm{~m}$ (rates excluding VAT, Bunker Adjustment Factor and other surcharges that may apply) on the ferry link between Helsingborg and Helsingør (6 km distance). Special rates apply for transit traffic that uses the Helsingør-Helsingborg ferry as well as the Puttgarden-Rødby or Rostock-Gedser ferry link (both connect Germany to Denmark): 311 euros for a truck of $13 \mathrm{~m}$ and 387 euros for a truck up to $19 \mathrm{~m}$. These are the official rates. In practice, the negotiated price for large customers for the combined ferry connection Helsingør-Helsingborg and Puttgarden-Rødby can be as low as 200 euros.

Another important fixed link is the Great Belt Fixed Link connecting the Danish towns of Korsør and Nyborg on the islands of Zealand (Sjælland) and Fyn (or Funen), respectively. It consists of a road suspension bridge and railway tunnel between Zealand and the islet Sprogø, as well as a box girder bridge between Sprogø and Funen. The link was opened to road traffic in 1998. The 2009 toll fees for trucks (10-19 m) amount to 142 euros including VAT (one way, figures, www.storebaelt. $\mathrm{dk}$, excluding discounts) or 114 euros excluding VAT. In our analysis, we use a market-based fee of 110 euros per transit. A combined use of the Oresund Link and the Great Belt Link thus costs about 195 euros (excluding VAT).

\subsection{Unit price/rate per kilometer $\left(p_{\mathrm{T}}\right.$ and $\left.p_{\mathrm{R}}\right)$}

The unit rates per kilometer are based on the cost functions for trucks and short sea vessels. The price per kilometer incurred by a truck/trailer combination (equivalent to a vessel slot of 17 lane meters capacity) when using a short sea service is presented in Fig. 6. The figures relate to the high scenario (MGO price of USD 1,000 per ton), but similar calculations were made for the base and low scenarios. The freight rate data and operational characteristics of the 17 roro/ropax services in the sample (see earlier section) formed the basis for the estimation of a lower and upper limit to the unit price per kilometer of sailing distance. By doing so, four curves for each scenario could be drawn: upper and lower curves when using HFO $(1.5 \%)$ and upper and lower curves when using MGO (0.1\%). The rates per kilometer for shorter distances are much higher since vessel load factors are lower and fixed costs (such as port dues) have a large impact on the cost structure on short distances. The effect of the fixed costs flattens out when trip distances become longer.

A detailed insight in the price structure of road transport is needed in view of comparing modal competition between road and short sea transport. The cost bases of trucking firms (and thus the trucking rates) vary considerably depending on the rolling stock used (e.g. new trucks versus older trucks), the country of registration of the company and its associated tax regime, driver costs, etc. Therefore, we present average price functions for four regions in Europe: (a) Benelux countries, France and 


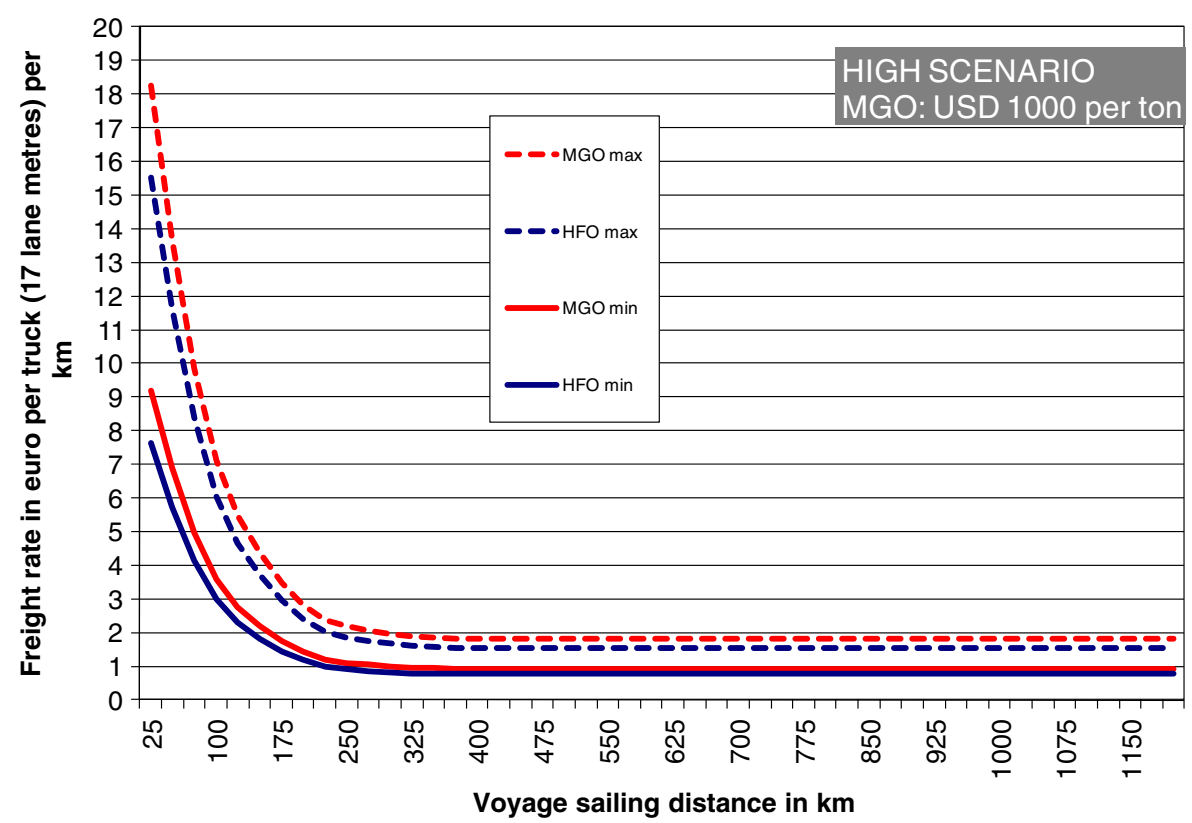

Fig. 6 Roro/ropax services: freight rate in euros per truck shipped per kilometer sailing distance-high scenario (MGO price of USD 1,000 per ton; source: own compilation based on market data)

Germany, (b) Eastern Germany and Poland, (c) the United Kingdom and (d) the Baltic States and Russia. We assume an average cargo load of 10 to 15 tons.

Figure 7 provides four price functions for road transport, expressed in euros per kilometer, for July 2008 (when fuel prices peaked). Similar price functions were

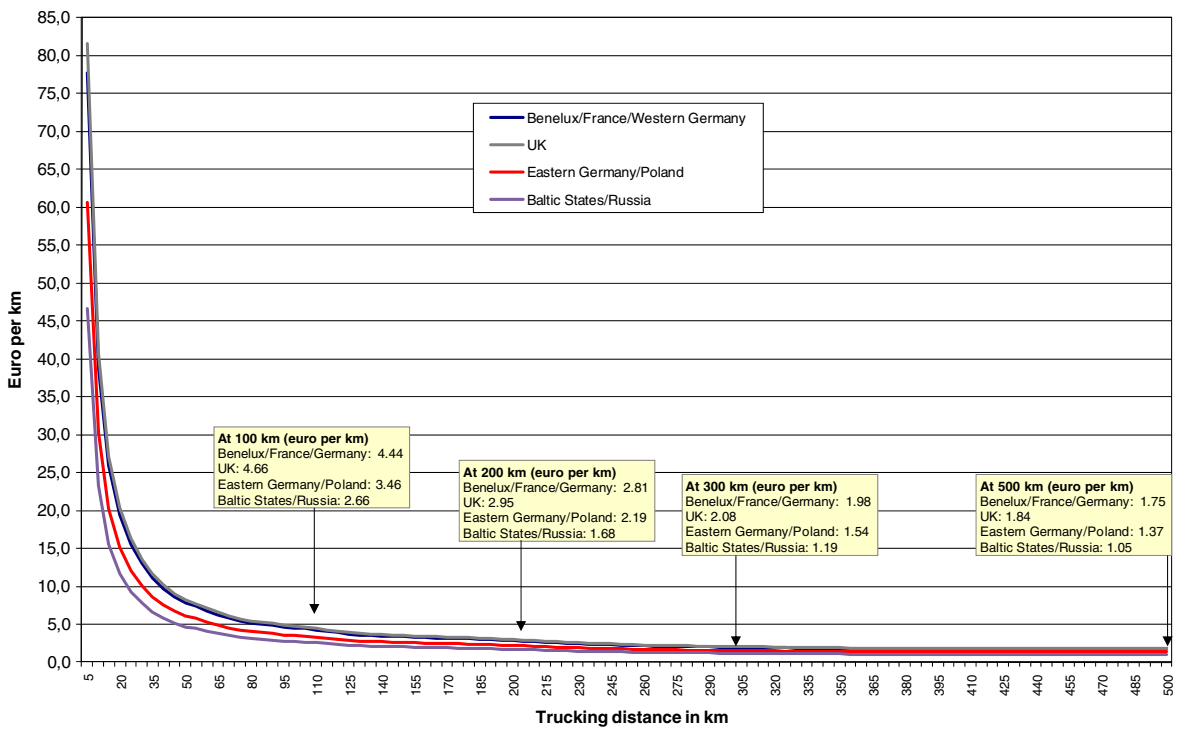

Fig. 7 Price functions for road haulage (in euros per kilometer)—July 2008 (source: own compilation based on market data) 
calculated for the other fuel price scenarios. All curves reach a horizontal asymptote starting from 300 to $350 \mathrm{~km}$. This implies that the cost per kilometer remains the same for each kilometer driven beyond this point. Below the $300 \mathrm{~km}$ threshold, the unit cost per kilometer changes with distance. This is caused by the practice of charging a fixed fee for deploying a truck. The longer the distance the less impact the fixed fee will have on the total cost per kilometer. The base cost function for trucking companies in the Benelux, France and Germany is derived from data obtained from market players. The cost curve levels out at around 1.75 euro per $\mathrm{km}$ for long distances in July 2008. The base cost function for Eastern Germany and Poland is estimated using Polish drivers. The average cost per kilometer for Polish trucking companies is significantly lower compared to companies from the other two regions considered. The cost curve for Poland levels out at around 1.37 euro per $\mathrm{km}$ (compared to 1.75 euro per $\mathrm{km}$ for the Benelux/France/Germany) for long distances in July 2008. The observed cost difference is not the result of fuel costs (diesel prices in Poland are very similar to the prices applicable in the Benelux/France/Germany), but is mainly caused by the gap in driver costs. Guihéry (2008) reports that the wages associated with one driving hour amount to 28.4 euros for France, 28.8 euros for the Netherlands, 25.9 euros for the western part of Germany, 15.4 euros for the eastern part of Germany and only 10 euros for Poland. The gap is not only the result of the absolute wage differences. It is also associated with the weekly working time and the ratio between driving time and working time. In our analysis, the unit cost per kilometer of Polish and East-German trucks is assumed to be $22 \%$ lower than for West German/Dutch trucking companies.

Latvian, Estonian and Russian drivers dominate the market to and from the Baltic States. The cost base of these trucking companies is much lower than the Polish case. When checking with Latvian forwarders and trucking companies, it was stated that the new wages per month for Latvian truck drivers would amount to 400 to 600 euros per month, compared to 800-900 euros for Polish drivers. Furthermore, the availability of cheap Russian diesel has a large impact on the cost base for these trucking companies. It is common practice to import Russian diesel in fuel tanks installed on old trucks and to fill the tanks of modern trucks once the Latvian/ Russian border has been crossed. Russian diesel prices are as low as 0.38 to 0.40 euro per liter including tax. Because of these factors, it is not exceptional to see Baltic and Russian trucking companies operate at a cost per kilometer up to a level of 1 euro per $\mathrm{km}$ or almost half of the operating costs of German or Dutch companies. Given these practices, the simulation model uses much lower trucking rates on routes to the Baltic States and Eastern Europe compared to routes in Western Europe. In our analysis, the unit cost per kilometer of Baltic and Russian trucks is assumed to be $40 \%$ lower than for West German/Dutch trucking companies.

The road haulage prices for UK companies are the highest of the four curves considered. Trucking companies based in the southeastern part of the United Kingdom on average face a 5\% higher cost per kilometer than their counterparts across the English Channel. This is mainly caused by the higher diesel prices in the United Kingdom.

The prices per vehicle- $\mathrm{km} p_{\mathrm{T}}$ and $p_{\mathrm{R}}$ presented in this section serve as a basis for the comparative analysis between the short sea/truck option and the 'truck only' option further in this study. In order to make this comparison realistic, we developed 
a nationality distribution of trucks operational on each of the four main short sea markets in North Europe. On the links between West Europe and Scandinavia, we primarily find Dutch and German truck drivers. Road haulage across the English Channel is dominated by West-European firms. Baltic and Russian drivers are dominant on the connections between West Europe and the Baltic States (Table 8).

Unit Price $p_{\mathrm{T}}$ also includes a compensation for the Eurovignet. We assume the costs of the Eurovignet for trucks will be fully passed on to the customers. For the integration of the Eurovignet in the analysis, we followed the approach as suggested by Skema (2010). COM (2008) 436 final/2 proposed amendments to Directive 1999/ $62 / \mathrm{EC}$ on the charging of heavy goods vehicles for the use of certain infrastructures. The proposal was based on the 'Handbook on estimation of external costs in the transport sector', produced within the study 'Internalisation Measures and Policies for All external Cost of Transport'. In this report, the Commission proposed that road users should also be charged, on a per kilometer basis, for air pollution, noise pollution and congestion in addition to current infrastructural tolls. Skema (2010) calculated that this would imply an average environmental charge per vehicle-km of 0.053 euro for EURO IV trucks and 0.034 euro for EURO V and VI trucks. These kilometer charges for environmental impact (external costs) are part of a proposed amendment to the current Eurovignet Directive and as such have not yet been ratified. In their study, Skema (2010) assumed that these charges will be ratified by the European Parliament and fully implemented and enforced by 2015 . We therefore assume that the proposed environmental tolls will be $100 \%$ implemented in their current form in 2015. We also follow the assumption that the current prescribed infrastructural tolls by 2015 will be $100 \%$ enforced compared to only $50 \%$ now. We assume that EURO VI trucks will be the norm by 2015.

Given the above assumptions, the additional charge per vehicle-km for EURO VI trucks would amount to 0.0385 euro per vehicle-km, i.e. an environmental charge of 0.034 euro per vehicle-km and an additional infrastructure charge of 0.0045 euro per vehicle-km. The $100 \%$ infrastructural toll upper limit for a EURO VI truck is 0.009 euro per vehicle-km, but since we assume $50 \%$ of this amount is already charged today, we stick to an additional infrastructure charge of 0.0045 euro per vehicle-km (see also Skema study). In our cost analysis, we use an additional charge caused by the Eurovignet of 0.0385 euro per vehicle-km. A full application of the Eurovignet will thus lead to an increase in the price per kilometer for trucks. However, this increase is quite modest as the base price per vehicle-km for West-European trucking companies amounts to around 1.75 euro; the additional charge of 0.0385 or an increase of about $2.2 \%$. Moreover, it is expected that this cost increase might be

Table 8 Distribution of truck nationalities on different routes (source: based on market information)

\begin{tabular}{lllll}
\hline & $\begin{array}{l}\text { Germany/Denmark } \\
\text { to Sweden }\end{array}$ & $\begin{array}{l}\text { English } \\
\text { Channel }\end{array}$ & $\begin{array}{l}\text { West Europe- } \\
\text { Baltic States }\end{array}$ & $\begin{array}{l}\text { West Europe- } \\
\text { Scandinavia }\end{array}$ \\
\hline Benelux/France/Western Germany & $75 \%$ & $50 \%$ & $20 \%$ & $70 \%$ \\
UK & $0 \%$ & $40 \%$ & $0 \%$ & $0 \%$ \\
Eastern Germany/Poland & $20 \%$ & $5 \%$ & $25 \%$ & $15 \%$ \\
Baltic States/Russia & $5 \%$ & $5 \%$ & $55 \%$ & $15 \%$ \\
\hline
\end{tabular}


compensated by a higher load factor on trucks, a more efficient truck technology, a partial compensation of the Eurovignet by a lowering by governments of the fixed costs of trucks (in particular the vehicle tax) and some of the variable costs (tax on diesel) and a further influx of East-European drivers on the West-European markets.

\subsection{Price model results}

We compare five prices for each of the 30 origin-destination relations:

- The total price for the 'truck only' option (i.e. truck is the only transport mode used on the origin-destination relation)

- The total minimum price for each combined truck/short sea option with a roro/ ropax vessel using HFO $(1.5 \%)$ as base fuel

- The total maximum price for each combined truck/short sea option with a roro/ ropax vessel using HFO (1.5\%) as base fuel

- The total minimum price for each combined truck/short sea option with a roro/ ropax vessel using $\mathrm{MGO}(0.1 \%)$ as base fuel

- The total maximum price for each combined truck/short sea option with a roro/ ropax vessel using $\mathrm{MGO}(0.1 \%)$ as base fuel

The differences between the minimum and maximum price scenarios for the truck/short sea options are linked to the price functions for roro/ropax vessels. The model output makes it possible to compare the 'truck only' option with one or more combined truck/short sea options for each of the scenarios regarding the evolution of the price of MGO and HFO. We limit the analysis to the high scenario and the low scenario.

The main conclusions of the price analysis can be divided in two groups. First of all, we can draw conclusions regarding the expected total cost changes per origindestination relation. The results are presented in Table 9 (high scenario) and Table 10 (low scenario). On origin-destination relations with an ultra-short or short maritime section (Calais-Dover, Putgarten-Rödby, Helsingör-Helsingborg and TravemündeTrelleborg), the total price increase typically ranges between $1 \%$ and $8 \%$ for the high scenario and $0.5 \%$ and $4 \%$ for the low scenario. Differences between these routes are partly the result of detour distances for trucks and the existence of fees for using fixed links. The more important the short sea section is in the total transport distance, the more impact the use of MGO $(0.1 \%)$ has on the total price for the truck/short sea option. For example, on the Rotterdam-Oslo route (no. 4.1), the price increase associated with the shift from HFO to MGO reaches about $11 \%$ to $12 \%$ in the high scenario when using the Ghent-Göteborg short sea link. When using shorter short sea links (alternatives 3 and 4), the price increase ranges between $1.1 \%$ and $3.4 \%$. In other words, the use of MGO is expected to increase the transport prices particularly on the origin-destination relations with a medium or long short sea section. Such a price development might eventually trigger a shift from medium and long short sea routes to shorter short sea routes or a 'truck only' alternative without any short sea section.

Secondly, we can draw conclusions regarding changes in the relative competitive position of the short sea/truck option versus the 'truck only' option when using 
Table 9 Impact of the use of MGO on the total price per routing alternative - expected price increases in $\%$ for transport between origin and destination (truck + short sea)-high scenario

\begin{tabular}{|c|c|c|c|c|c|c|}
\hline & \multicolumn{2}{|c|}{$\begin{array}{l}\text { Alternative } 2 \\
\text { (short sea }+ \text { truck) }\end{array}$} & \multicolumn{2}{|c|}{$\begin{array}{l}\text { Alternative } 3 \\
\text { (short sea }+ \text { truck) }\end{array}$} & \multicolumn{2}{|c|}{$\begin{array}{l}\text { Alternative } 4 \\
\text { (short sea }+ \text { truck) }\end{array}$} \\
\hline & roro $\min$ & roro $\max$ & roro $\min$ & roro $\max$ & roro $\min$ & roro $\max$ \\
\hline Germany/Denmark to Sweden & \multicolumn{2}{|c|}{$\begin{array}{l}\text { via Travemünde- } \\
\text { Trelleborg }\end{array}$} & \multicolumn{2}{|c|}{$\begin{array}{l}\text { via Putgarten-Rödby } \\
\text { and Oresund }\end{array}$} & \multicolumn{2}{|c|}{$\begin{array}{l}\text { via Putgarten-Rödby } \\
\text { and Helsingör- } \\
\text { Helsingborg }\end{array}$} \\
\hline 1.1. Dortmund-Göteborg & $3.2 \%$ & $4.8 \%$ & $1.4 \%$ & $2.4 \%$ & $2.0 \%$ & $3.2 \%$ \\
\hline 1.2. Dortmund-Stockholm & $2.3 \%$ & $3.6 \%$ & $1.1 \%$ & $1.9 \%$ & $1.6 \%$ & $2.5 \%$ \\
\hline English Channel & \multicolumn{2}{|c|}{ via Calais-Dover } & \multicolumn{2}{|c|}{ via Rotterdam-Harwich } & \multicolumn{2}{|c|}{ via Rotterdam-Hull } \\
\hline 2.1. Rotterdam-Tilburg & $5.0 \%$ & $7.0 \%$ & $6.9 \%$ & $8.9 \%$ & - & - \\
\hline 2.2. Rotterdam-London & $4.8 \%$ & $6.8 \%$ & $6.5 \%$ & $8.6 \%$ & - & - \\
\hline 2.3. Rotterdam-Portsmouth & $4.2 \%$ & $6.1 \%$ & $5.9 \%$ & $8.0 \%$ & - & - \\
\hline 2.4. Düsseldorf-Tilbury & $4.3 \%$ & $6.2 \%$ & $5.5 \%$ & $7.6 \%$ & - & - \\
\hline 2.5. Düsseldorf-London & $4.2 \%$ & $6.1 \%$ & $5.3 \%$ & $7.4 \%$ & - & - \\
\hline 2.6. Düsseldorf-Portsmouth & $3.7 \%$ & $5.5 \%$ & $4.2 \%$ & $6.1 \%$ & - & - \\
\hline 2.7. Brussels-Tilbury & $5.8 \%$ & $7.9 \%$ & $6.0 \%$ & $8.0 \%$ & - & - \\
\hline 2.8. Brussels-London & $5.8 \%$ & $7.8 \%$ & $5.9 \%$ & $7.9 \%$ & - & - \\
\hline 2.9. Brussels-Portsmouth & $5.0 \%$ & $7.0 \%$ & $4.8 \%$ & $6.8 \%$ & - & - \\
\hline 2.10. Dortmund-Tilbury & $4.1 \%$ & $5.9 \%$ & $5.3 \%$ & $7.4 \%$ & - & - \\
\hline 2.11. Dortmund-London & $3.9 \%$ & $5.8 \%$ & $5.1 \%$ & $7.1 \%$ & - & - \\
\hline 2.12. Dortmund-Portsmouth & $3.5 \%$ & $5.3 \%$ & $4.1 \%$ & $6.0 \%$ & - & - \\
\hline 2.13. Rotterdam-Manchester & $3.1 \%$ & $4.7 \%$ & $4.9 \%$ & $6.9 \%$ & $6.5 \%$ & $8.6 \%$ \\
\hline 2.14. Düsseldorf-Manchester & $2.8 \%$ & $4.3 \%$ & $3.5 \%$ & $5.2 \%$ & $5.3 \%$ & $7.4 \%$ \\
\hline 2.15. Brussels-Manchester & $3.5 \%$ & $5.2 \%$ & $3.9 \%$ & $5.7 \%$ & $6.0 \%$ & $8.1 \%$ \\
\hline 2.16. Dortmund-Manchester & $2.7 \%$ & $4.2 \%$ & $3.4 \%$ & $5.1 \%$ & $5.2 \%$ & $7.2 \%$ \\
\hline West Europe-Baltic States & \multicolumn{2}{|c|}{ via Lübeck-Riga } & \multicolumn{2}{|c|}{ via Kappelskär-Paldiski } & \multicolumn{2}{|c|}{$\begin{array}{l}\text { via Karlshamn- } \\
\text { Klaipeda }\end{array}$} \\
\hline 3.1. Dieppe-Tallin & $6.3 \%$ & $8.4 \%$ & - & - & - & - \\
\hline 3.2. Dieppe-Kaunas & $6.5 \%$ & $8.6 \%$ & - & - & - & - \\
\hline 3.3. Antwerpen-Tallin & $7.9 \%$ & $9.9 \%$ & - & - & - & - \\
\hline 3.4. Antwerpen-Kaunas & $8.1 \%$ & $10.1 \%$ & - & - & - & - \\
\hline 3.5. Amsterdam-Tallin & $7.8 \%$ & $9.8 \%$ & - & - & - & - \\
\hline 3.6. Amsterdam-Kaunas & $8.1 \%$ & $10.1 \%$ & - & - & - & - \\
\hline 3.7. Hamburg-Tallin & $12.5 \%$ & $13.4 \%$ & - & - & - & - \\
\hline 3.8. Hamburg-Kaunas & $12.8 \%$ & $13.7 \%$ & - & - & - & - \\
\hline 3.9. Esbjerg-Tallin & $9.5 \%$ & $11.3 \%$ & $2.6 \%$ & $4.0 \%$ & - & - \\
\hline 3.10. Esbjerg-Kaunas & $9.8 \%$ & $11.5 \%$ & - & - & $4.5 \%$ & $6.5 \%$ \\
\hline West Europe-Scandinavia & \multicolumn{2}{|c|}{ via Ghent-Göteborg } & \multicolumn{2}{|c|}{$\begin{array}{l}\text { via Travemünde- } \\
\text { Trelleborg }\end{array}$} & \multicolumn{2}{|c|}{ via Putgarten-Rödby } \\
\hline 4.1. Rotterdam-Oslo & $10.8 \%$ & $12.3 \%$ & $2.1 \%$ & $3.4 \%$ & $1.1 \%$ & $1.8 \%$ \\
\hline 4.2. Rotterdam-Stockholm & $9.2 \%$ & $11.0 \%$ & $2.1 \%$ & $3.3 \%$ & $1.1 \%$ & $1.8 \%$ \\
\hline
\end{tabular}


Table 10 Impact of the use of MGO on the total price per routing alternative - expected price increases in $\%$ for transport between origin and destination (truck + short sea)-low scenario

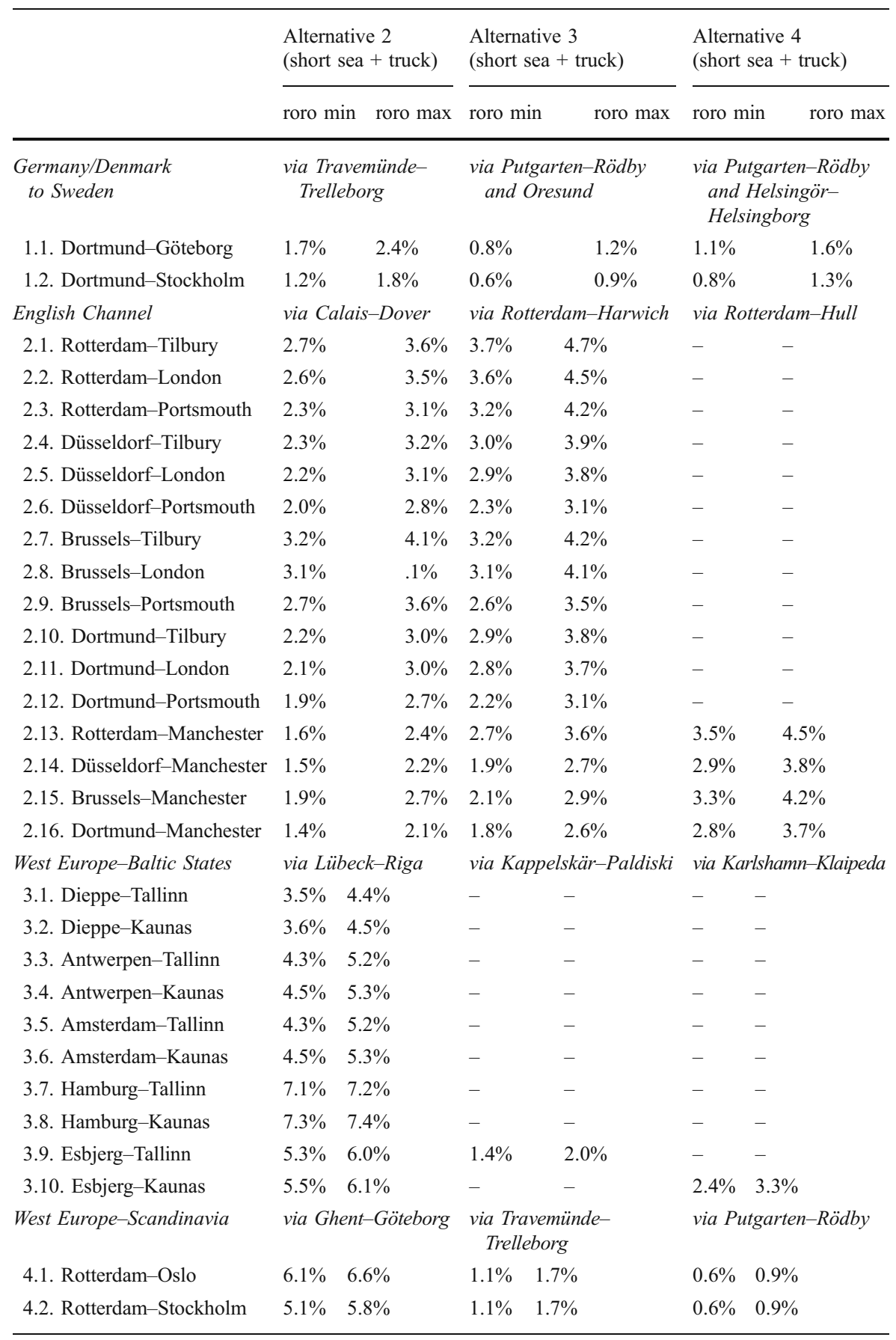


MGO (0.1\%) instead of HFO (1.5\%; per origin-destination relation). The results are presented in Table 11 (high scenario) and Table 12 (low scenario).

On the trade lane between Germany/Denmark and Sweden, the TravemündeTrelleborg ferry connection is competitive compared to the 'truck only' option. Trucks typically incur higher costs as a consequence of significant additional distances to be travelled and tolls linked to the use of the fixed links in Denmark (Great Belt and Oresund). For the shorter short sea routes (alternatives 3 and 4), the price difference between the combined truck/short sea solution and the 'truck only' option diminishes when using MGO instead of HFO up to a level where the 'truck only' option becomes more competitive. The observed price gap, though small, can trigger a modal shift from sea to road in the high scenario.

The cross channel short sea business for manned truck/trailer combinations is likely to be hit hard by the use of MGO. At present, the rate setting of short sea services on the Calais-Dover link is still competitive compared to the Eurotunnel shuttle services: the position of the ferry links ranges between a cost advantage of $6 \%$ to a cost disadvantage of up to $22 \%$ on some links. However, the use of MGO makes the price difference on the O-D relations considered shifts in favour of the freight rail shuttles through the Channel Tunnel. The combined truck/short sea solution ends up having a price disadvantage of 32\% (maximum) and $0 \%$ (minimum) compared to the truck/rail combination. These results suggest a potential modal shift from short sea services on the Calais-Dover link to rail services through the Channel Tunnel. The tunnel is estimated at $75 \%$ capacity prior to the fire and is at $50 \%$ capacity now. Eurotunnel is aggressively seeking to regain lost market share. The use of MGO $(0.1 \%)$ will allow Eurotunnel to introduce extra freight shuttles but, unless it abandons its strict cost-control strategy, Eurotunnel would presumably do so only if it thought they would be full, not on the off-chance of picking up the odd extra lorry. In summary, the use of MGO could well imply a major traffic loss of manned truck/trailer combinations per vessel across the southern part of the English Channel with potentially negative implications on the ferry capacity for passenger transfers. The Rotterdam-Harwich short sea link shows the most competitive profile on all routes considered except for traffic flows to and from Manchester (price dominance of Rotterdam-Hull), but also here the use of MGO is expected to make its competitive position weaker: the average price advantage over the truck/rail option via the Channel Tunnel in the high scenario decreases from $13 \%$ to $8 \%$. The narrowing of the price gap implies that the Rotterdam-Harwich short sea route moves towards a situation of increased competition with the truck/rail option. Such a development should raise great concern given longer truck distances on the already highly congested motorways in the southeast of the UK.

The transport connections between Western Europe and the Baltic States are expected to be heavily affected by the introduction of the new regulations on low sulphur requirements for vessels in the ECAs. While long-distance, short sea transport succeeds in keeping a price advantage over trucking on a number of O-D relations (see for example Hamburg-Tallinn), the ratio between the trucking price and the price for the truck/short sea combinations seriously deteriorates on most other routes. On the routes Dieppe-Kaunas and Amsterdam-Kaunas, short sea services are likely to completely lose their appeal to customers that imply major modal shifts away from the Lübeck-Riga short sea link. On the routes Hamburg- 


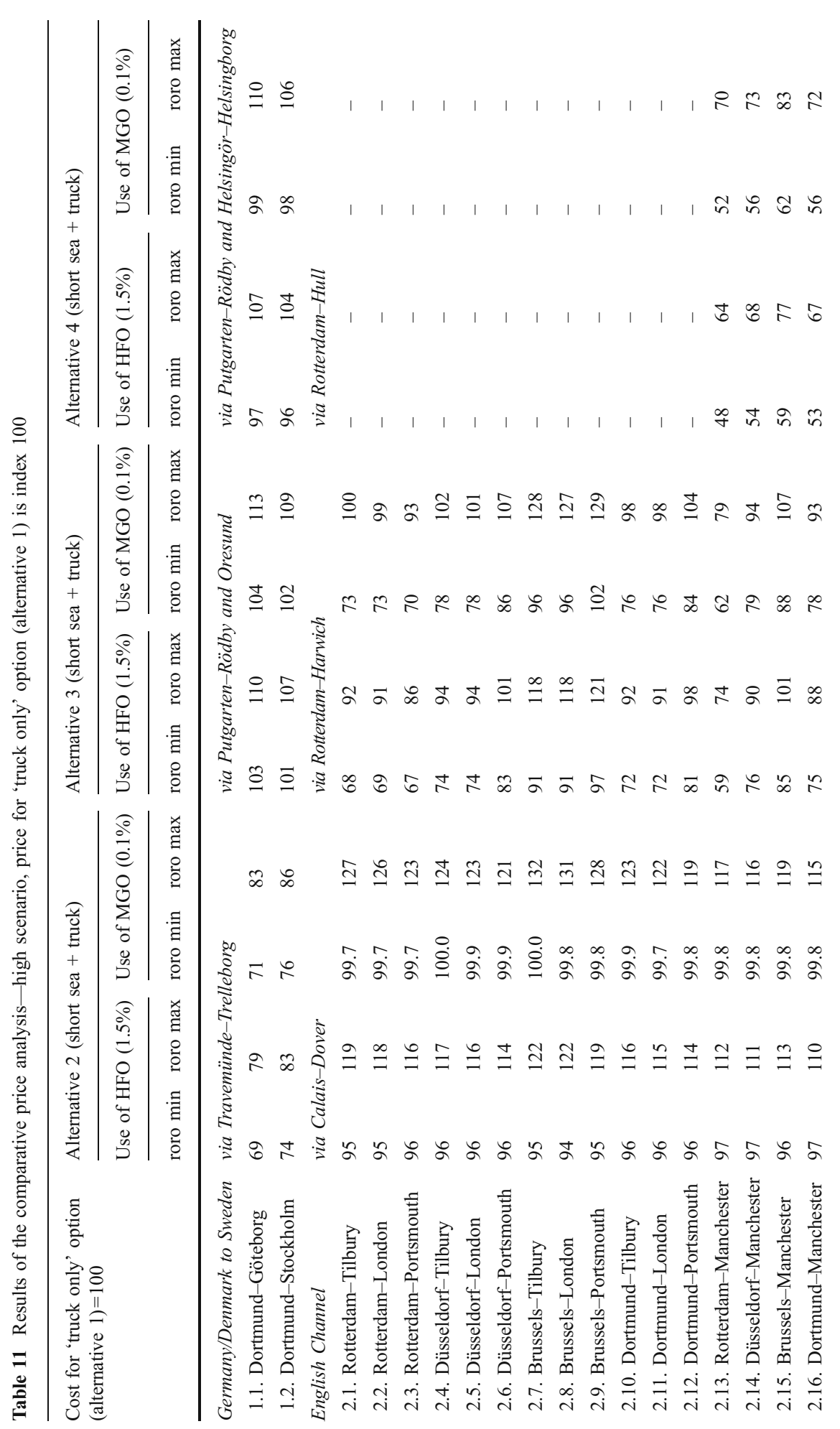




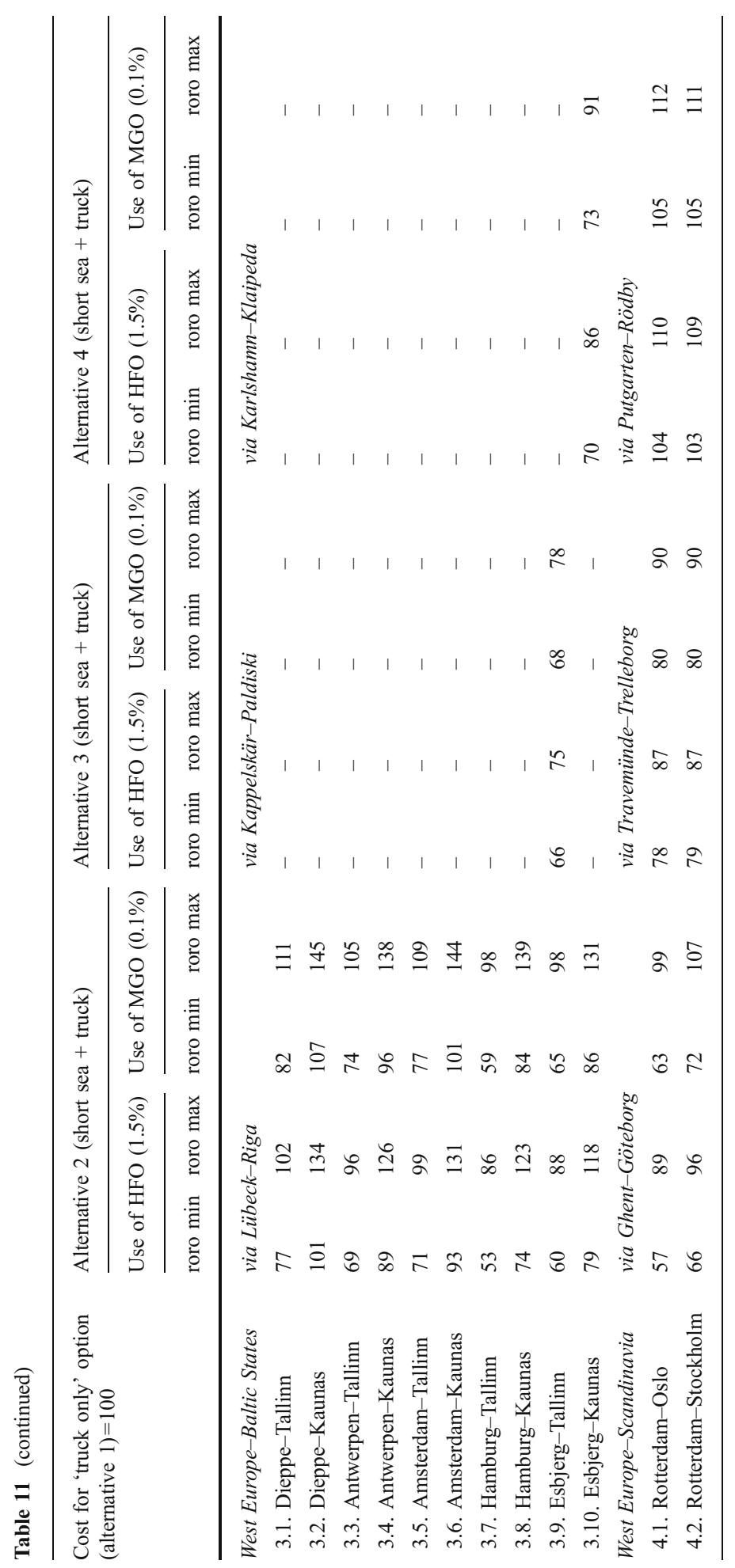




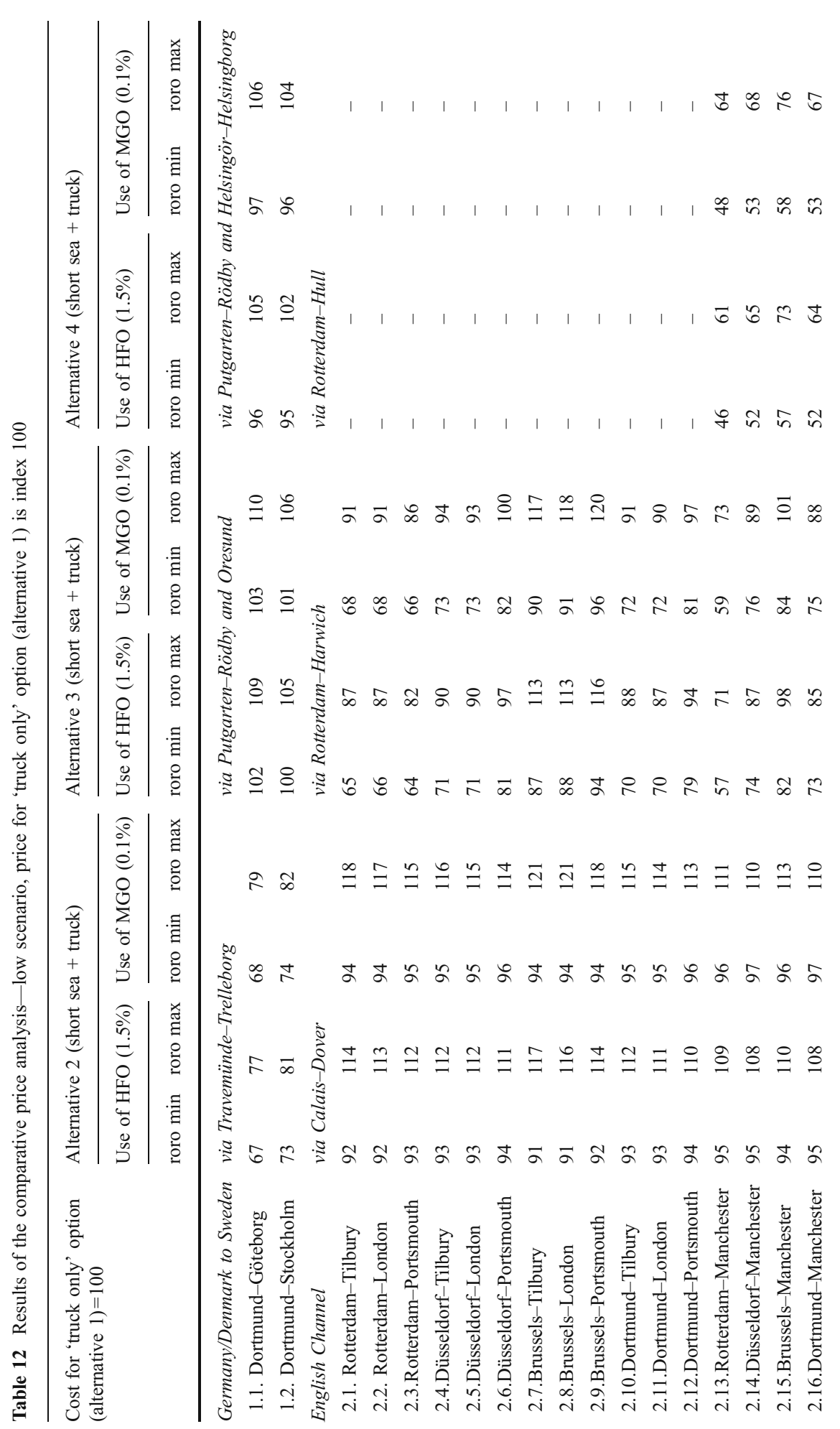




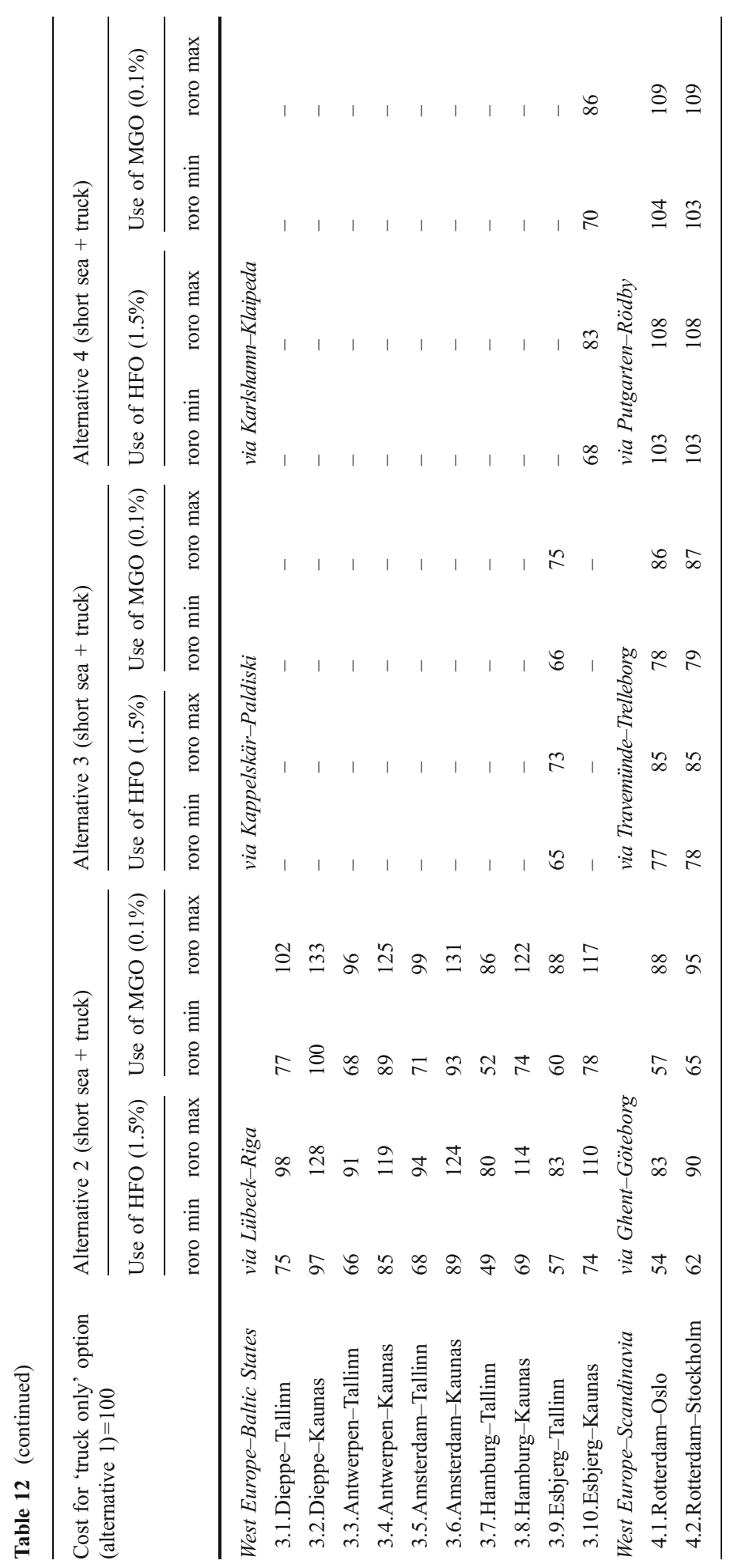


Kaunas and Antwerp-Kaunas, the price disadvantage for the long-distance short sea solution becomes too high to guarantee a high competitiveness vis-à-vis trucking. Alternative short sea routes 3 and 4 remain competitive for connecting Esjberg to the Baltic States, but also there the price difference shrinks when introducing MGO.

At present, the short sea connections between the Benelux/Western Germany and Scandinavia (Sweden and Norway in particular) face rather limited competition from road haulage. The main competitor is the much shorter short sea link between Travemünde and Trelleborg (which involves much longer trucking distances). Nevertheless, the use of MGO is expected to narrow down the cost advantage of the long-distance short sea option to such an extent that some customers might start opting for trucking goods instead of using short sea services. More certain is that the use of MGO will trigger a shift from long-distance to short-distance short sea links. Hence, the Travemünde-Trelleborg route clearly overtakes the Ghent-Göteborg route to become the cheapest solution between Rotterdam and Stockholm, while the price gap also closes on the Rotterdam-Oslo link.

The results for the low scenario are slightly more positive for short sea services than in the high scenario, but still the use of MGO $(0.1 \%)$ is expected to generate shifts from sea to road given the observed changes in the ratios between the truck prices and the truck/short sea prices.

\section{Implications on the modal shift}

The evolutions in price differences between the routing options indicate varying degrees of competition between the combined short sea/truck alternative and the 'truck only' alternative. In the previous section, we have demonstrated that the use of low sulphur fuels is expected to tilt the balance in the modal competition towards the 'truck only' option and shorter short sea routes on quite a number of origindestination relations. However, it remains extremely difficult to assess to what extent the changes in price competition will lead to actual modal shifts in favour of the 'truck only' option.

In order to have some insight in the impact of low sulphur use on the traffic distribution between trucks and short sea services, we use a stated-preference technique based on a survey among leading short sea operators in the ECAs. In April 2009 , a survey was sent out to a large number of short sea lines with operations in the ECAs. The survey aimed at assessing the perception of short sea operators on the potential volume losses and modal shift impacts linked to the implementation of strict low sulphur fuel requirements under different scenarios regarding fuel price evolutions. The survey contained the following two key questions: (1) How would the use of MGO impact freight rates in three fuel price scenarios? and (2) Can you estimate how much volume you would lose due to the assumed increases in freight rates? After an assessment of the quality of the obtained responses, data for 64 individual short sea services could be extracted. In 2008, these 64 services together carried 40.03 million passengers, 5.31 million freight units and 2.02 million TEU. Total transport performance reached 1.34 billion freight unit kilometers and 1.29 billion TEU-kilometer. To allow a more disaggregated analysis of the results, it was decided to make a distinction between four distance classes and four sub-markets. 
The distance classes include liner services with a one-way sailing distance of $0-125$, 125-400, 400-750 and longer than $750 \mathrm{~km}$. The sub-markets in the analysis coincide with the four geographical markets used in the price model.

Tables 13 and 14 show the results for the low and high fuel price scenarios. For the low scenario, the respondents expect freight rate increases in the order of $15 \%$ to $25 \%$ with an overall average of nearly $18 \%$. Rate increases are expected to be the highest on the longer routes. The corresponding volume losses are expected to reach $14.5 \%$. The routes covering medium-range distances $(400-750 \mathrm{~km})$ are likely to be hit the strongest with expected volume losses of $21 \%$ on average. The long-distance routes seem to be less affected. For the high scenario (USD 1,000 per ton), the expected impacts are considerable: a freight rate increase of up to $60 \%$ and anticipated volume losses of more than $50 \%$. The medium-distance routes would be worst hit.

Tables 13 and 14 also give the price elasticities of demand for short sea services based on the stated-preference technique. The price elasticity of demand is defined as the percentage change in demand over the percentage change in the price/freight rate. We underline that the questionnaire results show the views of operators on price elasticity, not the view of final users. The point-price elasticity for short sea services is negative around unity implying that a price increase by a certain percentage leads to a decrease in demand of a similar percentage. Long-distance short sea services are somewhat less price sensitive (values higher than -1). The services between the West-European mainland and the UK show the highest price elasticity. This confirms our earlier findings on the price competition between the 'truck only' option and the short sea options.

\section{Conclusions}

This paper aimed at analyzing the potential impact of the new low sulphur requirements on roro shipping in the ECAs. The paper focused on two research questions: (1) What is the expected impact of the new requirements of IMO on costs and prices of short sea traffic in the ECAs? and (2) What is the expected impact of the new requirements of IMO on the modal split in the ECAs?

Regarding the first research question, the effect of the new Annex VI agreement may be quite costly for the participants in the shipping industry. Based on historical price differences, the use of MGO $(0.1 \%)$ could well imply a cost increase per ton of bunker fuel of on average $80 \%$ to $100 \%$ (long term) compared to IFO 380 and $70 \%$ to $90 \%$ compared to LS 380 grades $(1.5 \%)$. The impact on shipping lines' cost base when shifting from HFO (1.5\%) to MGO would be considerable as well: a $25.5 \%$ increase in ship costs for the base scenario and even $30.6 \%$ on average for the high scenario with for a number of routes peaks of $40 \%$. The average ship cost increase for fast short sea/ropax ships (25 to 30 knots on average) is estimated at $29 \%$ for the low scenario and even $40 \%$ (ranging from $31 \%$ to $47 \%$ ) for the high scenario. A shift from HFO $(1.5 \%)$ to MGO $(0.1 \%)$ would have an impact on freight rates. The freight rate is defined here as the total unit price customers pay for using the short sea service (typically per 17 lane meters-equivalent to a truck/trailer combination). For 


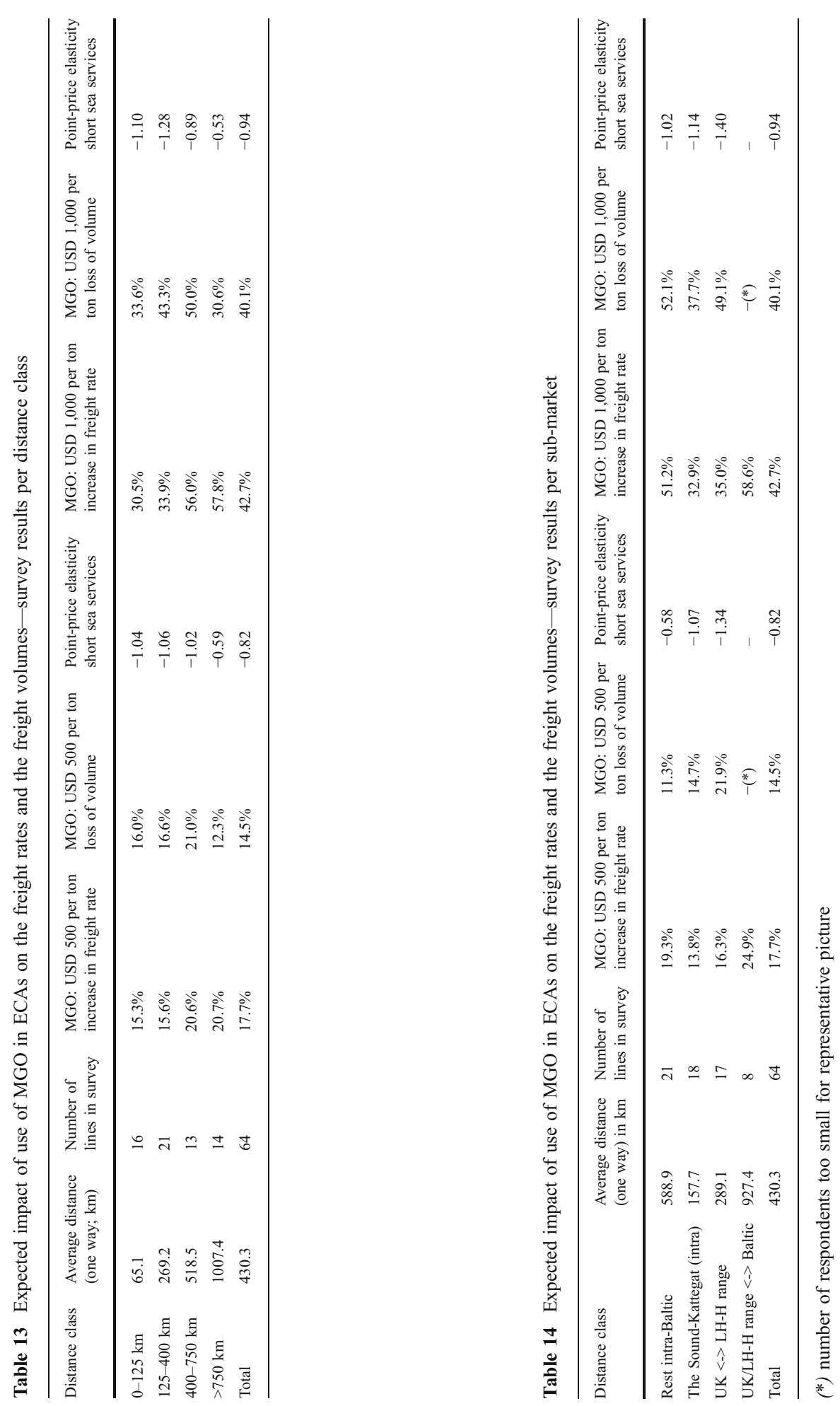


traditional short sea services, freight rate increases are estimated to reach $8 \%$ to $13 \%$ for the low scenario and around $20 \%$ for the high scenario. For fast short sea services, the figures are on average $25 \%$ for the low scenario and $40 \%$ for the high scenario. It must be stressed that all of the above figures are averages and that quite substantial differences might occur among the different liner services.

In view of answering the second research question, a detailed comparative price analysis was developed to assess modal competition between several short sea/truck routing options and the 'truck only' option on 30 origin-destination routes linked to the ECAs. All these short sea solutions face potential competition from a 'truck only' option (for Dover-Calais in combination with the Channel Tunnel). The use of MGO is expected to increase the transport prices particularly on the origindestination relations with a medium or long short sea section. Such a price development might eventually trigger a shift from medium and long short sea routes to shorter short sea routes or a 'truck only' alternative without any short sea section. The situation is particularly precarious for cross channel short sea business for manned truck/trailer combinations and the transport connections between Western Europe and the Baltic States. The observed shifts in price differences incurred when introducing MGO $(0.1 \%)$ as a base fuel in the ECAs would most likely lead to changes in the modal split at the expense of short sea services. A survey was conducted to assess the perception of short sea operators on the potential volume losses and modal shift impacts linked to the implementation of strict low sulphur fuel requirements under different scenarios regarding fuel price evolutions. Overall, the price elasticities of demand are close to -1 indicating that a price increase in short sea services with a specific percentage is expected to decrease the demand with a similar percentage.

Even relatively small traffic losses (e.g. $10 \%$ to $20 \%$ less cargo) for existing short sea services can trigger a vicious cycle of capacity reduction and lower frequencies ultimately leading to a poorer position for short sea services and thus an unattractive market environment for investors. Vicious cycles characterized by the downsizing of short sea activities and the closures of lines can lead to an overall implosion of a short sea sub-market, leaving room to the 'truck only' option or short sea services on short or ultra-short distances to fill the gap in the market.

This paper provided a pure economic analysis on the impact of the low sulphur fuel requirements of IMO on short sea shipping in the ECAs. Future research can address its ecological impact in terms of overall emissions. If no modal shift would take place, marginal external costs of short sea vessels would obviously decrease due to the new requirements. If the effect of a possible backshift to trucking is taken into account, a modal shift towards trucks and shorter short sea routes could partly or completely mitigate the initial effect of lowering the emissions. The combination of the economic analysis provided in this paper and an ecological analysis will allow to fully assess the ramifications of the low sulphur fuel requirements.

Acknowledgements This paper is based on a study on the impact of low sulphur fuel requirements commissioned by the European Community Shipowners' Associations (ECSA). The author would like to thank Mr. Alfons Guinier, Secretary-General of ECSA, for making this research possible. The views and opinions expressed by the author do not necessarily state or reflect those of ECSA or any of its members. 


\section{References}

Banister D, Button K (eds) (1993) Transport, the environment and sustainable development. E\&FN Spon, London

Campisi D, Gastaldi M (1996) Environmental protection, economic efficiency and intermodal competition in freight transport. Transp Res C Emerg Technol 4:391-406

Chapman L (2007) Transport and climate change: a review. J Transp Geogr 15:354-367

Cofala J (2007) Analysis of policy measures to reduce ship emissions in the context of the revision of the national emissions ceilings directive. IIASA for EC DG ENV. Laxenburg, Austria, p 74.

Corbett J, Koehler H (2003) Updated emissions from ocean shipping. J Geophys Res 108:D20

Derwent R, Stevenson D, Doherty R, Collins W, Sanderson, Johnson C, Cofala J, Mechler R, Amann M, Dentener F (2005) The contribution from shipping emissions to air quality and acid deposition in Europe. Ambio 34:54-59

Endresen O, Sørgard E, Sundet J, Dalsøren S, Isaksen I, Berglen T, Gravir G (2003) Emission from international sea transportation and environmental impact. J Geophys Res 108:D17

European Commission-Directorate General Environment (2002) Advice on impact of reduction in sulphur content of marine fuels marketed in the EU. Study/C.1/01/2002. European Commission, Brussels

Eyring V, Corbett J, Lee D, Winebrake J (2007) Brief summary of the impact of ship emissions on atmospheric composition, climate, and human health. Document submitted to the Health and Environment sub-group of the International Maritime Organization, 6 November 2007

Eyring V, Isaksen I, Berntsen T, Collins W, Corbett J, Endresen O, Grainger R, Moldanova J, Schlager H, Stevenson D (2009) Transport impacts on atmosphere and climate: shipping. Atmos Environ. doi:10.1016/j.atmosenv.2009.04.059

Friedrich R, Bickel P (2001) Environmental external costs of transport. Springer, Berlin

Guihéry L (2008) International road freight transport in Germany and the Netherlands: driver costs analysis and French perspectives. European Transport Conference, Noordwijkerhout

Industrierna S (2009) Information paper-consequences for the pulp and paper industry due to new sulphur regulations for ships. Swedish forest Industries Federation, Stockholm

Krystallon (2008) Sea water scrubbing - does it contribute to increased global CO2 emissions? Krystallon, West Sussex

Notteboom T, Vernimmen B (2009) The effect of high fuel costs on liner service configuration in container shipping. J Transp Geogr 17:325-337

Notteboom T, Vanherle K, Delhaye E (2010) Analysis of the consequences of low sulphur fuel requirements. Study commissioned by the European Community Shipowners' Associations (ECSA). University of Antwerp, Antwerp

Potter S, Enoch M (1997) Regulating transport's environmental impacts in a deregulating world. Transp Res D Transp Environ 2:271-282

Psaraftis H, Kontovasa C (2010) Balancing the economic and environmental performance of maritime transportation. Transport and Environment, Transportation Research Part D. doi:10.1016/j. $\operatorname{trd} .2010 .05 .001$

Skema (2010) Impact Study of the future requirements of Annex VI of the MARPOL Convention on Short Sea Shipping. Directorate-General for Energy and Transport, European Commission, Brussels

Swedish Maritime Administration (2009) Consequences of the IMO's new marine fuel sulphur regulations. SMA, Stockholm

Van Wee B, Janse P, Van Den Brink R (2005) Comparing energy use and environmental performance of land transport modes. Transp Rev 25:3-24

Vanherle K, Delhaye E (2010) Road versus short sea shipping: comparing emissions and external costs. Proceedings of the Annual Conference of the International Association of Maritime Economists (IAME). IAME, Lisbon

Wang H, Liu D, Dai G (2009) Review of maritime transportation air emission pollution and policy analysis. J Ocean Univ China (English Edition) 8:283-290 